\title{
CSF Findings in Acute NMDAR and LGI1 Antibody-Associated Autoimmune Encephalitis
}

\author{
Marc Dürr, Gunnar Nissen, Kurt-Wolfram Sühs, MD, Philipp Schwenkenbecher, MD, Christian Geis, MD, \\ Marius Ringelstein, MD, Hans-Peter Hartung, MD, Manuel A. Friese, MD, Max Kaufmann, MD, \\ Michael P. Malter, MD, Marie Madlener, MD, Franziska S. Thaler, MD, Tania Kümpfel, MD, Makbule Senel, MD, \\ Martin G. Häusler, MD, Hauke Schneider, MD, Florian Then Bergh, MD, Christoph Kellinghaus, MD, \\ Uwe K. Zettl, MD, Klaus-Peter Wandinger, MD, Nico Melzer, MD, Catharina C. Gross, PhD, Peter Lange, \\ Jens Dreyhaupt, PhD, Hayrettin Tumani, MD, Frank Leypoldt, MD, and Jan Lewerenz, MD, on behalf of the \\ German Network for Research on Autoimmune Encephalitis
}

Neurol Neuroimmunol Neuroinflamm 2021;8:e1086. doi:10.1212/NXI.0000000000001086

\section{Abstract}

\section{Background and Objectives}

CSF in antibody-defined autoimmune encephalitis (AE) subtypes shows subtype-dependent degrees of inflammation ranging from rare and often mild to frequent and often robust. AEs with NMDA receptor antibodies (NMDAR-E) and leucine-rich glioma-inactivated protein 1 antibodies (LGI1-E) represent opposite ends of this spectrum: NMDAR-E with typically frequent/robust and LGI1-E with rare/mild CSF inflammation. For a more in-depth analysis, we characterized CSF findings in acute, therapy-naive NMDAR-E and LGI1-E in a multicentric, retrospective, cross-sectional setting.

\section{Methods}

Eighty-two patients with NMDAR-E and 36 patients with LGI1-E from the GErman NEtwork for Research of AuToimmune Encephalitis (GENERATE) with lumbar puncture within 90 days of onset and before immunotherapy were included. CSF parameters comprised leukocytes, oligoclonal bands (OCBs), and CSF/serum ratios for albumin, immunoglobulin $\mathrm{G}(\operatorname{IgG}), \mathrm{A}(\operatorname{IgA})$, and $\mathrm{M}(\operatorname{IgM})$, the latter 3 converted to $\mathrm{Z}$ scores according to Reiber formulas. The MRZ reaction was tested in 14 patients with NMDAR-E and 6 patients with LGI1-E, respectively.

\section{Results}

CSF was abnormal in 94\% of NMDAR-E but only in 36\% of LGI1-E patients. Robust quantitative intrathecal immunoglobulin synthesis (IIS, $\operatorname{IgG}>\operatorname{IgM}>>\operatorname{IgA}$ ) was characteristic for NMDAR-E, but absent in LGI-E. In NMDAR-E, CSF leukocytes were higher when IIS was present or more pronounced. In addition, in NMDAR-E, CSF leukocytes were lower and IIS occurred less often and if so to a lesser degree at older age. Patients with NMDAR-E with severe functional impairment more often had positive OCBs. In CSF obtained later than 3 weeks of onset, leukocytes were lower. In parallel, the correlation of leukocytes with IIS disappeared as IIS was partially independent of disease duration. The MRZ reaction was positive in $5(36 \%)$ patients with NMDAR-E. All these associations were completely absent in

\author{
Correspondence \\ Dr. Lewerenz \\ jan.lewerenz@uni-ulm.de
}

\begin{abstract}
From the Department of Neurology (M.D., M.S., J.D., H.T., J.L.), Ulm University; Department of Neurosurgery (M.D.), University Hospital Tübingen; Neuroimmunology (G.N., K.-P.W., F.L.), Institute of Clinical Chemistry, University Hospital Schleswig-Holstein Kiel/Lübeck; Department of Neurology (K.-W.S., P.S.), Hannover Medical School; Department of Neurology (C.G.), University Hospital Jena; Department of Neurology (M.R., H.-P.H., N.M.), Medical Faculty, Heinrich Heine University Düsseldorf; Department of Neurology (M.R.), Center for Neurology and Neuropsychiatry, LVR-Klinikum Düsseldorf, Düsseldorf; Institute of Neuroimmunology and Multiple Sclerosis (M.A.F., M.K.), University Medical Center Hamburg-Eppendorf; Department of Neurology (M.P.M., M.M.), University of Cologne, Faculty of Medicine and University Hospital; Institute of Clinical Neuroimmunology (F.S.T., T.K.), University Hospital and Biomedical Center, Ludwig-Maximilians University Munich; Department of Pediatrics (M.G.H.), University Hospital RWTH Aachen; Technische Universität Dresden (H.S.), and Department of Neurology, University Hospital Augsburg; Department of Neurology (F.T.B.), University Hospital Leipzig; Department of Neurology (C.K.), Klinikum Osnabrück; Department of Neurology (U.K.Z.), Section for Neuroimmunology, University Hospital Rostock; Department of Neurology with Institute of Translational Neurology (N.M., C.C.G.), University Hospital Münster; Department of Neurology (P.L.), University Hospital Göttingen; Institute of Epidemiology and Medical Biometry, Ulm University; and Department of Neurology (F.L.), University Hospital Schleswig-Holstein and Kiel University, Germany.

Go to Neurology.org/N for full disclosures. Funding information and disclosures deemed relevant by the authors, if any, are provided at the end of the article.
\end{abstract}

German Network for Research on Autoimmune Encephalitis coinvestigators are listed in Appendix 2 at links.Iww.com/NXI/A640.

The Article Processing Charge was funded by the authors.

This is an open access article distributed under the terms of the Creative Commons Attribution-NonCommercial-NoDerivatives License 4.0 (CC BY-NC-ND), which permits downloading and sharing the work provided it is properly cited. The work cannot be changed in any way or used commercially without permission from the journal. 


\section{Glossary}

$\mathbf{A E}=$ autoimmune encephalitis; $\mathbf{A M P A}=\alpha$-amino-3-hydroxy-5-methyl-4-isoxazolepropionic acid; $\mathbf{A I}=$ antibody index; AQP4 = aquaporin-4; CASPR2 = contactin-associated protein-like 2; DPPX = Dipeptidyl-peptidase-like protein-6; GABA = $\gamma$-aminobutyric acid; GENERATE $=$ German Network of Research on Autoimmune Encephalitis; IIS = immunoglobulin synthesis; IQR = interquartile range; LGI1-E = leucine-rich glioma-inactivated protein 1; LP = lumbar puncture; MOG = myelin oligodendrocyte protein; $\mathbf{m R S}=$ modified Rankin Scale; $\mathbf{M R Z}$ reaction = measles-rubella-zoster reaction; NMDAR-E = NMDA receptor; OCB = oligoclonal band; VZV = varicella zoster.

LGI1-E. Here, younger patients showed more blood-CSF barrier dysfunction. In LGI1-E, but not in NMDAR-E, the bloodCSF barrier was more dysfunctional when CSF leukocytes were higher.

\section{Discussion}

NMDAR-E and LGI-E differ in their typical extent of CSF inflammation. In addition, the patterns formed by the different inflammatory CSF parameters and their relationship with disease severity, age, and disease duration are subtype-characteristic. Moreover, signs for multiple sclerosis-like chronic inflammation are present in a subgroup of patients with NMDAR-E. These CSF patterns might be markers for the different immunopathogeneses of LGI1-E and NMDAR-E.

The 2 most common subtypes of autoimmune encephalitis $(\mathrm{AE})$ are $\mathrm{AE}$ with antibodies against NMDA receptors (NMDAR-E) and AE with leucine-rich glioma inactivated protein-1 (LGI1-E). ${ }^{1,2}$ NMDAR-E and LGI1-E are quite different: NMDAR-E mostly affects young women, ${ }^{3}$ whereas LGI1-E tends to occur more frequently at older age and in men. ${ }^{2}$ NMDAR-E typically progresses to a global encephalitic syndrome with decreased consciousness, stereotypic movements, and vegetative dysfunction, ${ }^{3}$ whereas LGI1-E is a typical limbic AE. ${ }^{2}$ On cranial MRI, many patients with LGI1$\mathrm{E}$ show mesiotemporal T2-hyperintensities, ${ }^{2}$ whereas in NMDAR-E, the MRI is frequently normal, although heterogeneous lesions also involving white matter are found in about half of the patients. ${ }^{3}$ A recent systematic analysis of diverse $\mathrm{AE}$ subtypes with regard to published basic CSF parameters comprising leukocytes, total protein, and oligoclonal bands (OCBs) revealed 2 different clusters: together with AEs with contactin-associated protein-like 2 (CASPR2), $\gamma$-aminobutyric acid $\left(\mathrm{GABA}_{\mathrm{A}}\right)$, and glycine receptor antibodies, LGI1E typically showed scarce and infrequent CSF inflammation, whereas robust and frequent inflammation was characteristic for NMDAR-E and AEs with dipeptidyl-peptidase-like protein-6 (DPPX, GABA ${ }_{B}$, and $\alpha$-amino-3-hydroxy-5-methyl-4isoxazolepropionic acid (AMPA) receptor antibodies. ${ }^{4}$ To complement this systematic analysis, ${ }^{4}$ we performed a multicentric retrospective analysis of the detailed inflammatory CSF findings in therapy-naive patients with LGI1- and NMDAR-E enrolled in the registry of the German Network of Research on Autoimmune Encephalitis (GENERATE) with CSF obtained within 90 days from clinical onset. The parameters included not only CSF leukocytes, blood-CSF barrier function, and OCBs but also quantitative intrathecal immunoglobulin synthesis for immunoglobulin G ( $\operatorname{IgG}$ ), A ( $\operatorname{IgA})$, and $\mathrm{M}(\operatorname{IgM})$. For a subset of patients with $\mathrm{CSF} /$ serum samples still available, an analysis of the $M R Z$ reaction $(M=$ measles, $\mathrm{R}=$ rubella, $\mathrm{Z}=$ varicella zoster $[\mathrm{VZV}]$ ), a marker for polyspecific intrathecal synthesis of pathogen-specific IgG typical of MS was analyzed. The mutual interactions of different CSF parameters and their associations with disease duration, severity, and age were analyzed.

\section{Methods}

\section{Patient Identification}

GENERATE is a multicentric, combined retrospective and prospective registry for patients with $\mathrm{AE}$ in Germany (generate-net.de/) recruiting since 2013. For this project, patients were selected according to the following criteria: (1) enrollment before January 1, 2017, (2) NMDAR antibodies in CSF or LGI1 antibodies in serum and/or CSF positive, (3) no recent infectious encephalitis, and (4) complete first CSF examination, including leukocyte count, OCB, and $\mathrm{CSF} /$ serum ratios for albumin $\left(\mathrm{Q}_{\mathrm{Alb}}\right), \operatorname{IgG}\left(\mathrm{Q}_{\mathrm{IgG}}\right), \operatorname{IgA}$ $\left(\mathrm{Q}_{\mathrm{gA}}\right)$, and $\operatorname{IgM}\left(\mathrm{Q}_{\mathrm{gM}}\right)$ obtained within 90 days after onset without prior immunomodulatory therapy (Figure 1). Basic demographic variables, clinical presentation, MRI and EEG findings, as needed to test the fulfillment of recently suggested diagnostic criteria for $\mathrm{AE},{ }^{5}$ and severity of functional impairment at the time of lumbar puncture (LP) as the modified Rankin Scale (mRS) score ${ }^{6}$ were extracted from the GENERATE database.

\section{Normal Values and Reiber Formulas}

All laboratory analyses except pathogen-specific CSF/serum antibody indices (AIs) were performed locally at the time of LP. Pleocytosis was defined as $>4$ leukocytes $/ \mu \mathrm{L}$. Age-normalized $\mathrm{Q}_{\mathrm{Alb}}\left(\mathrm{Q}_{\mathrm{Alb}} / \mathrm{Q}_{\mathrm{lim}}\right)$ was calculated by dividing $\mathrm{Q}_{\mathrm{Alb}}$ by the agedependent upper limit $\left(\mathrm{Q}_{\text {lim }} ; 4+\right.$ age $\left./ 15 \times 10^{-3}\right){ }^{7}$ When CSF IgM was below the lower limit of quantification, $\mathrm{Q}_{\mathrm{gg}}$ was calculated with the CSF IgM set to the lowest level of detection of the respective laboratory. For 2 data points, the lower limits of quantification were not available. Thus, these data points were 


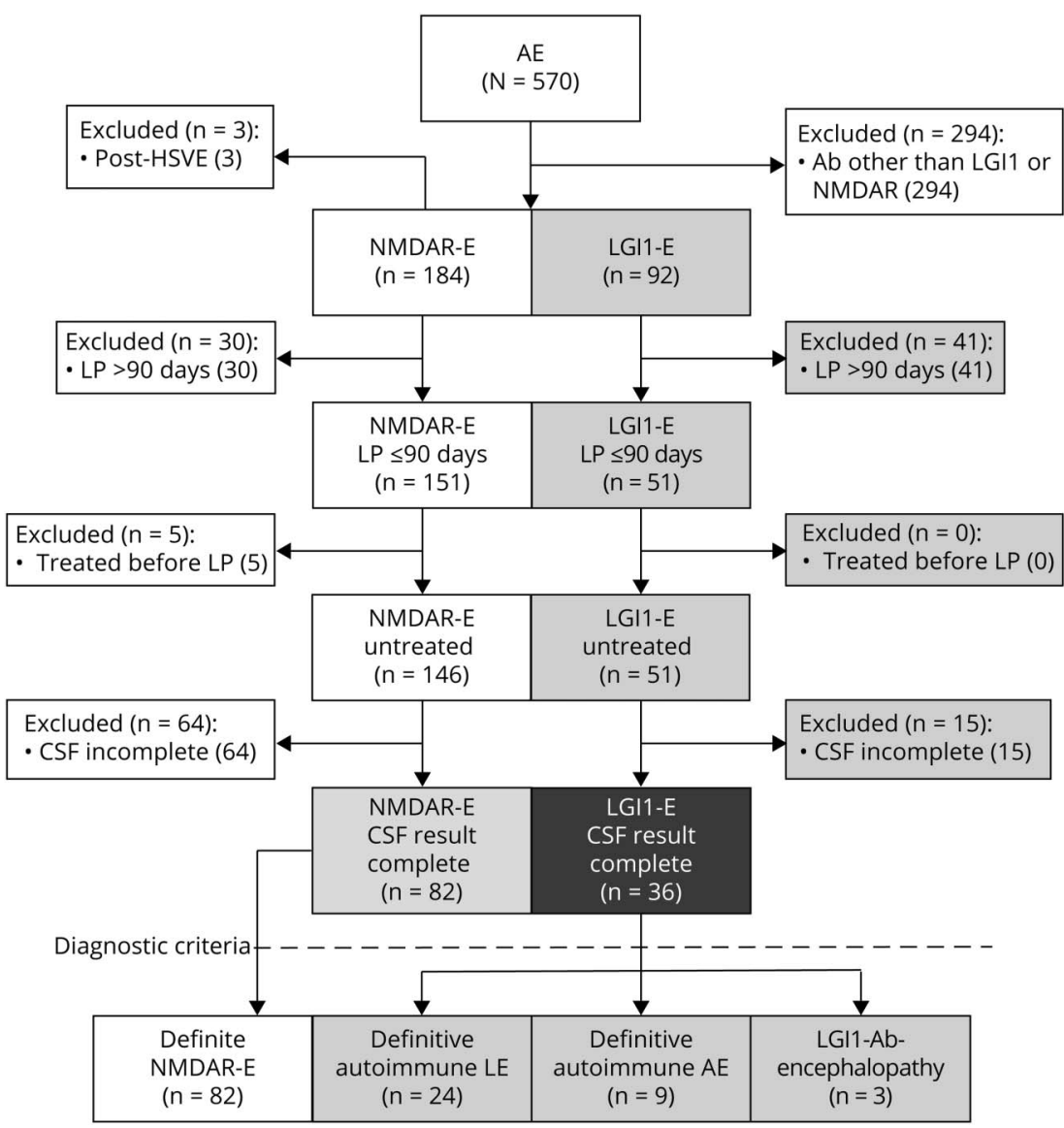

Flowchart depicting the enrollment process. $A E=$ autoimmune encephalitis; HSVE = herpes simplex virus encephalitis; $A B=$ antibody. omitted from the univariate analysis and imputed as median $\mathrm{Q}_{\mathrm{IgM}}$ of the respective $\mathrm{AE}$ subtype for multivariate analyses. The definitive quantitative IIS of IgG, IgA, and IgM for Table was diagnosed when $\mathrm{Q}_{\mathrm{IgG}}, \mathrm{Q}_{\mathrm{IgA}}$ and $\mathrm{Q}_{\mathrm{IgM}}$ were higher than the upper limit, $\mathrm{Q}_{\text {lim(high), }} \mathrm{Q}_{\text {mean }}+3 \mathrm{SD}$ according to Reiber ${ }^{8}$ formulas. Reiber diagrams were generated using the CSF Research Tool/Reibergrams (Albaum IT-Solutions, Frankfurt am Main, Germany). For IIS Z scores, the difference of each $\mathrm{Q}_{\mathrm{IgG} / \mathrm{A} / \mathrm{M}}$ from $\mathrm{Q}_{\text {mean }}$ was converted into the number of SDs above or below $\mathrm{Q}_{\text {mean }}$. $Z$ scores were categorized as different IIS probabilities: $\mathrm{Z}>3$ definitive, $2<\mathrm{Z} \leq 3$ probable, $1<\mathrm{Z} \leq$ 2 possible, and $\leq 1$ unlikely (eFigure $1 \mathrm{~A}$, links.lww.com/ NXI/A600). Z sores were graphically presented and adjusted as described in the Supplementary Methods Section (eFigures 1-4, links.lww.com/NXI/A600).

\section{Quantification of Pathogen-Specific CSF/Serum Antibody Indices}

Pathogen-specific AIs for measles, rubella, and VZV from the initial CSF/serum samples were determined centrally and retrospectively using ELISAs (Virion \Serion, Würzburg, Germany) according to the manufacturer with the following modifications: sera were diluted $1: 5,000$ and 1:20,000, CSF 1: 25 and $1: 100$, incubated for 3 hours at $37^{\circ} \mathrm{C}$ under constant agitation $(250 \mathrm{rpm})$, and detection antibody was replaced by a horse-radish peroxidase-coupled rabbit anti-human IgG (Dako Agilent, Waldbronn Germany, \#P0214). AIs were calculated as described with an upper normal limit of 1.4 . $^{9}$ The data for the 14 patients with NMDAR-E and 6 patients with LGI1-E reported here are analyzed in more detail with additional patients and pathogen-specific AIs in the accompanying publication. ${ }^{10}$

\section{Statistics}

Statistical analysis was performed using GraphPad Prism (GraphPad Inc., La Jolla, US) and SAS, version 9.4 (SAS Institute Cary, NC). Categorical variables were analyzed using the Fisher exact test or $\chi^{2}$ test as appropriate. For ordinal and continuous variables, the median and interquartile range (IQR) were calculated. The Mann-Whitney $U$ test was used for 2 and the Kruskal-Wallis test followed by the Dunn multiple comparisons test for more than 2 groups. The Spearman rank correlation and the Pearson correlation coefficient were used to investigate associations between 2 continuous variables as appropriate. The mRS score was dichotomized into 2 groups, 0-2 (mild impairment) and 3-5 (severe impairment). Because of the differences in group size and range in ages, the NMDAR-E cohort was trichotomized according to age $(\leq 20$ years, $21-40$ years, and $>40$ years), whereas the LGI-E cohort was dichotomized ( $\leq 60$ years vs $>60$ years), a strategy that led 
Table Statistical Comparison of CSF Findings in Patients With Untreated Acute NMDAR and LGI1 Encephalitis

\begin{tabular}{|c|c|c|c|}
\hline & NMDAR-E (N = 82) & LGI1-E (N = 36) & $p$ Value \\
\hline Cells/ $\mu \mathrm{L}$, median (IQR) & $16.5(6.0-53.3)$ & $1.5(1.0-3.0)$ & $<0.0001$ \\
\hline Pleocytosis, N (\%) & $65(79)$ & $4(11)$ & $<0.0001$ \\
\hline Pleocytosis $>50$ cell $/ \mu \mathrm{L}, \mathrm{N}(\%)$ & $21(26)$ & $0(0)$ & 0.0004 \\
\hline Age-corrected $Q_{\text {Alb }}\left(Q_{\text {Alb }} / Q_{\text {lim }}\right)$, median (IQR) & $0.8(0.6-1.2)$ & $0.8(0.6-0.9)$ & 0.1695 \\
\hline Blood-CSF barrier dysfunction $\left(Q_{A l b}>Q_{\text {lim }}\right), N(\%)$ & $32(39)$ & $5(14)$ & 0.0090 \\
\hline \multicolumn{4}{|l|}{ Intrathecal immunoglobulin synthesis, N (\%) } \\
\hline Qualitative IgG synthesis (isolated CSF OCB) & $59(72)$ & $7(19)$ & $<0.0001$ \\
\hline Quantitative intrathecal IgG synthesis $\left(Q_{\mathrm{IgG}}>\mathbf{Q}_{\lim }\right)$ & $36(44)$ & $0(0)$ & $<0.0001$ \\
\hline Quantitative intrathecal IgA synthesis $\left(Q_{\operatorname{lgA}}>Q_{\lim }\right)$ & $12(15)$ & $0(0)$ & 0.0170 \\
\hline Quantitative intrathecal IgM synthesis $\left(Q_{\lg M}>Q_{\lim }\right)^{a}$ & $28(35)$ & $0(0)$ & $<0.0001$ \\
\hline Intrathecal IgG synthesis only (OCB positive) & $29(35)$ & $7(19)$ & 0.1276 \\
\hline Quantitative intrathecal IgG/A synthesis & $2(2)$ & $0(0)$ & 1.0000 \\
\hline Quantitative intrathecal IgG/M synthesis & $18(22)$ & $0(0)$ & 0.0014 \\
\hline Quantitative intrathecal IgG/A/M synthesis & $10(12)$ & $0(0)$ & 0.0307 \\
\hline Measles Al increased & $3 / 14(21)$ & $0 / 6(0)$ & 0.5211 \\
\hline Rubella Al increased & $6 / 14(43)$ & $1 / 6(17)$ & 0.3544 \\
\hline Varicella zoster Al increased & $5 / 14(36)$ & $0 / 6(0)$ & 0.2604 \\
\hline Number of increased Als, median (IQR) & $1(0-2)$ & $0(0-0)$ & 0.0757 \\
\hline \multicolumn{4}{|l|}{ Combinations of CSF pathologies, $\mathrm{N}(\%)$} \\
\hline Pathologic CSF result & $78(95)$ & $13(36)$ & $<0.0001$ \\
\hline Inflammatory CSF (pleocytosis and/or OCB) & $74(90)$ & $10(28)$ & $<0.0001$ \\
\hline Pleocytosis only & $9(11)$ & $2(6)$ & 0.5000 \\
\hline Ig synthesis only (at least CSF OCB) & $7(9)$ & $5(14)$ & 0.5087 \\
\hline Blood-CSF barrier dysfunction only & $4(5)$ & $3(8)$ & 0.4349 \\
\hline Pleocytosis + Ig synthesis & $29(35)$ & $1(3)$ & $<0.0001$ \\
\hline Pleocytosis + blood-CSF barrier dysfunction & $5(6)$ & $1(3)$ & 0.6656 \\
\hline Blood-CSF barrier dysfunction + Ig synthesis & $1(1)$ & $1(3)$ & 0.5189 \\
\hline All 3 pathologies & $23(28)$ & $0(0)$ & $<0.0001$ \\
\hline
\end{tabular}

Abbreviations: $\mathrm{Al}$ = antibody index; IQR = interquartile range; LGI1-E = leucine-rich glioma-inactivated protein 1; NMDAR-E = NMDA receptor; OCB = oligoclonal band; $\mathrm{Q}_{\text {lim }}=$ upper limit of normal $\mathrm{Q}_{\mathrm{Alb}}{ }^{7} ; \mathrm{Q}_{\mathrm{Alb}} / \mathrm{Q}_{\mathrm{lim}}=$ albumin CSF/serum ratio normalized by the age-dependent upper limit for normal.

The Fisher exact test was used for nominal variables, and the Mann-Whitney $U$ test was used for ordinal or continuous variables.

a Data available for 80 patients. $p$ values $<0.05$ are in bold.

to subcohorts not disproportionately different in size for univariate analysis. Multiple logistic regression and multiple linear regression analyses were performed to investigate the effect of different parameters on categorical and continuous variables, respectively. For these analyses, patients with NMDAR-E were dichotomized by age applying a cutoff of 20 years as indicated by the univariate analyses. Complex associations are graphically presented as results from locally weighted scatterplot smoothing. A 2-sided $p$ value of $<0.05$ was regarded as statistically significant. In addition, $p$ values $\geq 0.05$ but $<0.1$ were categorized as just failing to reach statistical significance. Because of the explorative nature of this study, all results from statistical tests have to be interpreted as hypothesis generating.

\section{Data Availability}

The data sets generated and/or analyzed during the current study are not publicly available but can be obtained by qualified researchers from the corresponding author on reasonable request. 


\section{Ethics}

All patients or their legal representatives gave their informed consent. The study was approved by the Institutional Review Board of the University of Schleswig-Holstein (\#13-162).

\section{Results}

\section{Study Cohorts}

At database lock, 570 patients with $\mathrm{AE}$ were enrolled in the GENERATE registry, of whom 184 and 92 were documented as NMDAR-E and LGI1-E, respectively (Figure 1). Of those, 82 documented as NMDAR-E and 36 documented as LGI1-E fulfilled all inclusion criteria. According to recent criteria, ${ }^{5}$ all patients with NMDAR-E had definitive NMDAR-E, whereas 24 of 36 patients documented as LGI1-E had definitive autoimmune limbic AE (67\%) and only 9 patients with LGI1-E fulfilled the criteria for definitive $\mathrm{AE}(25 \%)$. Three patients with LGI1-E (8\%) were diagnosed with anti-LGI1-associated cognitive impairment ${ }^{11}$ (Figure 1). The selected subcohorts were largely representative of all NMDAR and LGI1 antibodypositive patients (eTable 1, links.lww.com/NXI/A600).

\section{Higher CSF Leukocytes and More Frequent Blood-CSF Barrier Dysfunction and OCBs in NMDAR-E Compared With LGI1-E}

CSF leukocytes in NMDAR-E (median 16.5 cells $/ \mu \mathrm{L}$ ) were $>10$-fold higher than in LGI1-E (1.5 cells/ $\mu \mathrm{L}$, Table 1, Figure 2A). CSF leukocytes $>50 / \mu \mathrm{L}$ were found exclusively in NMDAR-E (Table 1). Although the median age-adjusted $\mathrm{Q}_{\mathrm{Alb}}$ in LGI1-E and NMDAR-E did not differ, increased $\mathrm{Q}_{\mathrm{Alb}} \mathrm{S}$ occurred twice as often in NMDAR-E (Table 1, Figure 2B). Finally, CSF-restricted OCBs were positive in two-thirds of NMDAR-E, but in less than one-fifth of the patients with LGI1-E (Table 1, Figure 2C). In LGI-E, but not in NMDAR$\mathrm{E}$, the age-adjusted $\mathrm{Q}_{\mathrm{Alb}}$ was higher when CSF leukocytes were also higher (eFigure 5A, links.lww.com/NXI/A600). In contrast, CSF leukocytes in NMDAR-E, but not in LGI-E (eFigure 5B, links.lww.com/NXI/A600), were higher in OCB-positive patients (median, IQR; OCB-: 7/ $\mu \mathrm{L}, 2-14$ / $\mu \mathrm{L} ; \mathrm{OCB}+: 27 / \mu \mathrm{L}, 9-73 / \mu \mathrm{L})$. Overall, CSF was pathologic in $94 \%$ and $36 \%$ of patients with NMDAR-E and LGI1-E, respectively (Table 1).

Relevant Quantitative Intrathecal IgG, IgA, and IgM Synthesis Is Characteristic for NMDAR-E but Not LGI-E

For many patients with NMDAR-E, Reiber diagrams showed definitive quantitative IIS $\left(\mathrm{Q}_{\mathrm{Ig}}>\mathrm{Q}_{\mathrm{lim}}\right)$ not only for IgG and IgM but also for IgA (eFigure 6, links.lww.com/NXI/A600, Table 1). The corresponding $\mathrm{Z}$ scores (eFigure $1 \mathrm{~A}$, see eMethods, links.lww.com/NXI/A600) were significantly higher in NMDAR-E compared with LGI1-E for all Ig classes (Figure 2D). All IIS Z scores were strongly associated with each other in NMDAR-E (eFigure 7A, links.lww.com/NXI/ A600), but not in LGI1-E (eFigure 8A, links.lww.com/NXI/ A600). In NMDAR-E, $Z$ scores $>3$ indicating definitive quantitative IgG, IgM, and IgA IIS occurred in $38 \%, 35 \%$, and $15 \%$, respectively (Figure $2 \mathrm{E}$ ). None of the patients with LGI1-E showed either probable or definitive quantitative IIS. Overall, IIS, especially for IgM, was more pronounced in NMDAR-E patients with higher CSF leukocytes (eFigure 7B, links.lww.com/NXI/A600). No such association was found in LGI1-E (eFigure 8B, links.lww.com/NXI/A600). The observation that higher leukocytes coincided with more pronounced IIS in NMDAR-E across the whole data set resulted from values obtained within 1 week of onset (eFigure 14, links.lww.com/NXI/A600). This association disappeared when LP was performed at later time points. Of interest, IIS of NMDAR-specific IgG correlated neither with quantitative IIS for total IgG nor with the presence of OCB (eFigure 7D, links. lww.com/NXI/A600). The MRZ reaction measured in a subset of patients with the initial CSF/serum samples still available was positive for 5/14 patients with NMDARE (36\%, Figure 2F), but for none of 6 patients with LGI-E. No major selection bias was identified when comparing the patients with NMDAR-E and LGI1-E tested for the MRZ reaction with patients without biosamples available (eFigures 9 and 10, links.lww.com/NXI/A600).

\section{Effect of Disease Duration on Inflammatory CSF Changes in NMDAR-E and LGI1-E}

Patients were categorized according to disease duration (1 week, $2 / 3$ weeks, $\geq 4$ weeks) at the time of LP. The resulting subgroups were quite similar $\left(\chi^{2}\right.$ test, $p=0.83$, eFigure 12 , A-C, links.lww.com/NXI/A600). CSF leukocytes in NMDAR-E, but not in LGI-E, were significantly lower when the LP was delayed (weeks 1-3: median 28.0 cells $/ \mu \mathrm{L}$, IQR 8.0-76.0; $\geq 4$ weeks: median 9.0 cells $/ \mu \mathrm{L}, 3.5-19.5$; MannWhitney $U$ test, $p<0.01$; Figure 3A; eFigure 12D, links.lww. com/NXI/A600). In both NMDAR- and LGI-E, OCBs became slightly more frequent over time. However, these trends were not significant (Figure 3C). In NMDAR-E with early LP, quantitative IIS was virtually identical to those with later LP (Figure 3D), however, with a trend toward higher values for $\operatorname{IgG}$ ( $\mathrm{Z}>3$ weeks $1-3,18 / 57,32 \%$, vs $\geq 4$ weeks, $13 / 25$, 52\%, Fisher exact test, $p=0.09$, Figure 3D). Of interest, IIS was present even in a substantial proportion of patients with LP within the first 3 days after clinical onset (eFigure 13A, links. lww.com/NXI/A600). For IgG and IgA, the disappearance of the association between IIS and CSF leukocytes at later time points coincided with a relative increase in the ratio of IIS to CSF leukocytes (eFigure 14, links.lww.com/NXI/A600).

At Younger Age, Pleocytosis and Intrathecal Ig Synthesis Are More Pronounced in NMDAR-E, Whereas the Blood-CSF Barrier Is More Dysfunctional in Younger Patients With LGI1-E Patients with NMDAR-E were subgrouped into young $(\leq 20$, $\mathrm{N}=17$ ), intermediate (21-40 years; $\mathrm{N}=43$ ), and older ( $>40$ years, $\mathrm{N}=22)$ patients. To obtain roughly equal subgroup sizes, the LGI1-E cohort was dichotomized only ( $<60$ years, $\mathrm{N}=16$; $\geq 60$ years, $\mathrm{N}=20$ ). Although older patients were more likely to be male, the resulting subgroups for each $\mathrm{AE}$ 

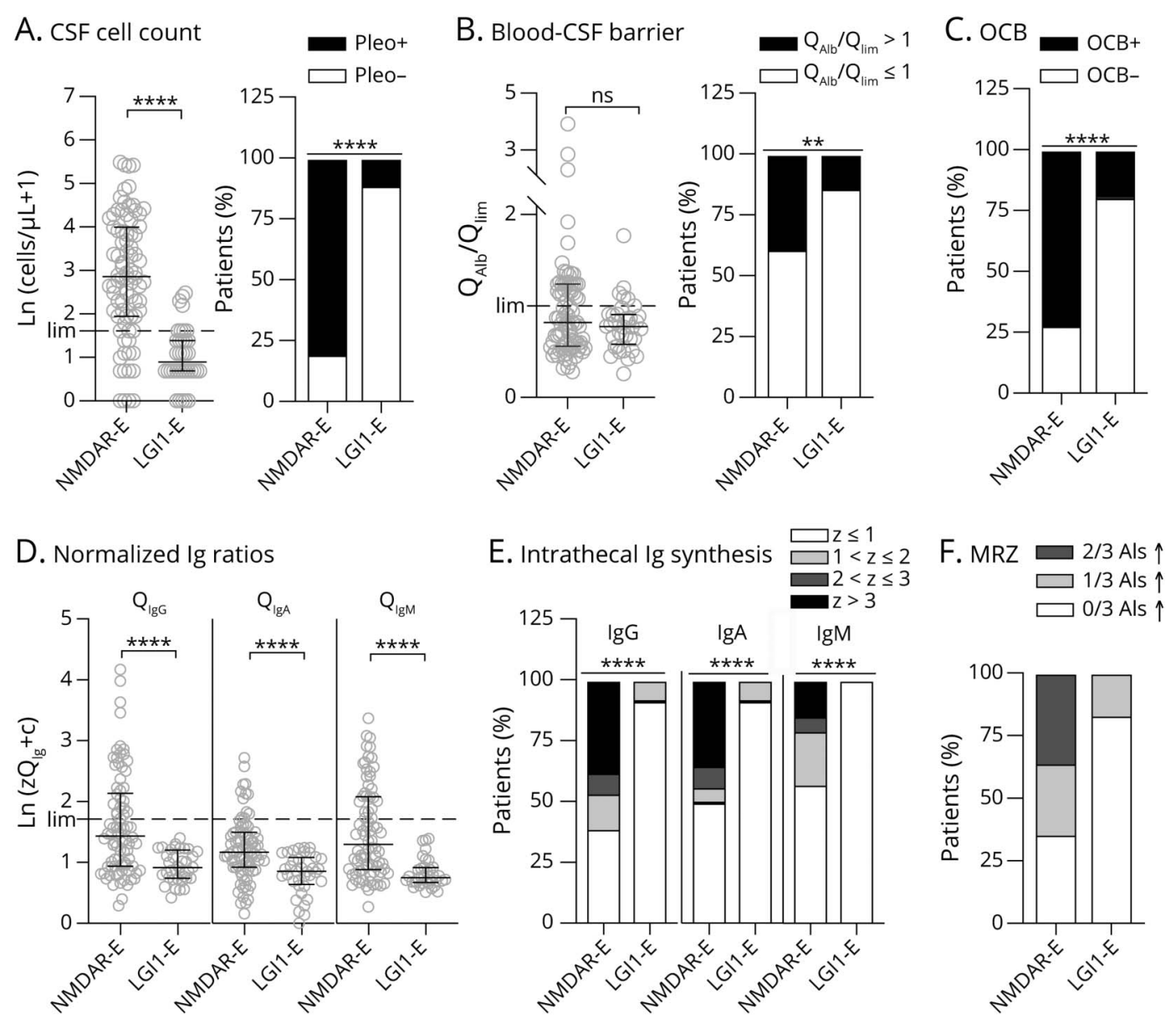

In 82 and 36 patients with therapy-naive NMDAR- and LGI1-E undergoing lumbar puncture within 90 days after onset of symptoms, basic CSF findings, cell count (A), age-adjusted blood-CSF barrier function $\left(\mathrm{Q}_{\mathrm{Alb}} / \mathrm{Q}_{\mathrm{lim}}, \mathrm{B}\right)$, and the presence of isolated oligoclonal bands (OCB) in CSF as most sensitive proof for intrathecal IgG synthesis (C) were compared. (A) CSF leukocytes counts were logarithmized after adding 1 , thus $\operatorname{Ln}($ cell count +1 ) in patients with 0 cells/ $\mu \mathrm{L}$ is 0 . (B) The individual CSF/serum albumin ratio (QAlb) was normalized by division with the age-dependent upper limit [Q $\left.\mathrm{Q}_{\mathrm{lim}}, 4+\mathrm{age}(\mathrm{yrs}) / 15\right]$. (D) CSF/serum IgG, IgA, and IgM ratios $\left(\mathrm{Q}_{\mathrm{IgG}}, \mathrm{Q}_{\mathrm{IgA}}\right.$, and $\left.\mathrm{Q}_{\mathrm{IgM}}\right)$ were compared with the expected mean CSF/serum ratio with regard to the individual $\mathrm{Q}_{\mathrm{Alb}}$ calculated by the Reiber formulas (traditional Reiber diagrams can be found in eFigure 4, links.lww.com/NXI/A600). The distance from the mean $\mathrm{Q}_{1}$ is expressed as the number of standard deviations (Z score), with a Z score $>3$ judged as a proof of intrathecal synthesis (black), a Z score $\leq 3$ but $>2$ classified a probable intrathecal synthesis (dark gray), and a Z score $\leq 2$ but $>1$ classified a possible intrathecal synthesis (light gray). The resulting Z scores were logarithmized after adding the correction factor $\mathrm{c}(2.51)$, resulting in $\mathrm{Ln}\left(\mathrm{z} \mathrm{O}_{\mathrm{g}}+\mathrm{c}\right.$ ) of 0 in the patient with LGI1-E with the lowest Z score for $\mathrm{Q}_{\mathrm{IgA}}$ (additional information in eFigures 1 and 2, links. Iww.com/ NXI/A600). (D) Comparison of the quantitative intrathecal IgG, IgA, and IgM synthesis in patients with NMDAR-E with patients with LGI1-E. (E) Frequency of intrathecal IgG, IgA, and IgM synthesis classified as present, probable, possible, or absent in both groups of patients. (F) Detection of a polyspecific immune activation using 3 pathogen-specific Als for measles, rubella, and varicella zoster virus in a subset of patients with NMDAR-E $(N=14)$ and LGI-E $(N=6)$. Two elevated Als (>1.4): dark gray, 1 elevated Al: light gray, no elevated Al: clear. The upper normal limits (lim, A: 4 leukocytes $\left./ \mu \mathrm{L}, \mathrm{B}: \mathrm{Q}_{\mathrm{Alb}} / \mathrm{Q}_{\lim }=1.0, \mathrm{D}: \mathrm{Q}_{\mathrm{mean}}+3 \mathrm{SD}\right)$ are indicated as dashed lines. Statistical analysis was performed using the Mann-Whitney $U$ test (A/B, left panels, D) and Fisher exact test of the unnormalized number of patients (A/B, right panel, C/E). ns = not significant, $* \star x p 0.01$, and $* \star \star \star x p<0.0001$ (additional analyses in eFigures 5 and $7-11$, links.Iww.com/NXI/ A600). Al = antibody index; LGI1-E = leucine-rich glioma-inactivated protein 1; NMDAR-E = NMDA receptor.

subtype were quite similar (eFigure 15, A-C, links.lww.com/ NXI/A600).

In NMDAR-E, at younger age CSF leukocytes were considerably higher ( $\leq 20$ years: median 28.0 cells $/ \mu \mathrm{L}$, IQR $16.0-88.5$, >40 years: median 6.0 cells $/ \mu \mathrm{L}$, IQR $1.5-31.5$; Figure 4A, eFigure 16A, links.lww.com/NXI/A600). An increased age-adjusted $\mathrm{Q}_{\mathrm{Alb}}$ was more frequent in older patients with NMDAR-E (Figure 4B). For pleocytosis and CSF-blood barrier dysfunction, rather gradual changes were observed across the 3 age groups (Figures 4, A and B). For OCBs and quantitative IIS, only the youngest age group differed from the 2 groups of older patients. The latter 2 were thus combined for statistical analysis (Figures 4, C and D). OCBs were $>2.5$ fold more frequently absent in older patients $(21 / 65,32 \%)$ compared with younger patients $(2 / 17,12 \%)$. Correspondingly, definitive IgG IIS ( $\mathrm{z}>3$ ) was $>1.5$-fold more frequent in young patients with NMDAR-E (10/17, $59 \%$ vs $21 / 65$, $32 \%)$. However, these differences were not statistically significant ( $p=0.13$ and $p=0.05$, respectively). IgA and IgM Z scores and the frequencies of definitive IgA and IgM IIS were significantly lower in older patients with NMDAR-E (Figure 4D). In LGI1-E, the only age-related difference detected was a considerably higher age-adjusted $\mathrm{Q}_{\mathrm{Alb}}$ in younger patients (eFigure 15, D-G, and eFigure 16, A and B, links.lww.com/NXI/A600). 
Figure 3 In NMDAR-E, Quantitative Intrathecal Immunoglobulin Synthesis IIS Is Largely Independent of Disease Duration, Whereas CSF Leukocytes Are Higher Early After Clinical Onset
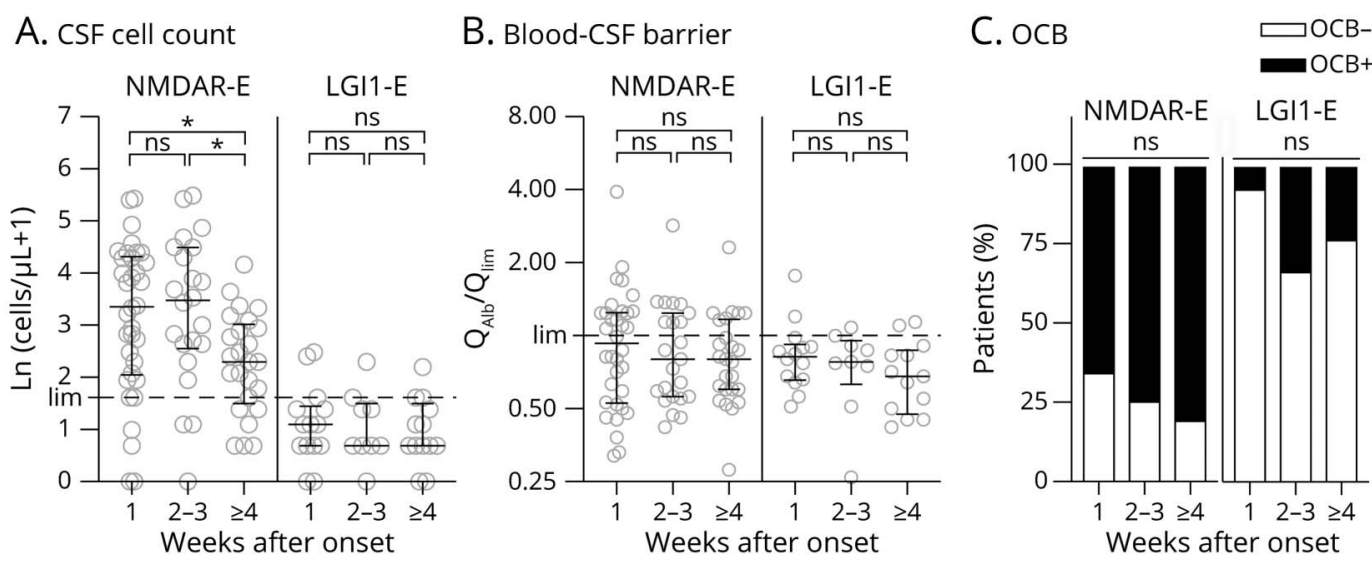

D. NMDAR-E: Intrathecal immunoglobulin synthesis
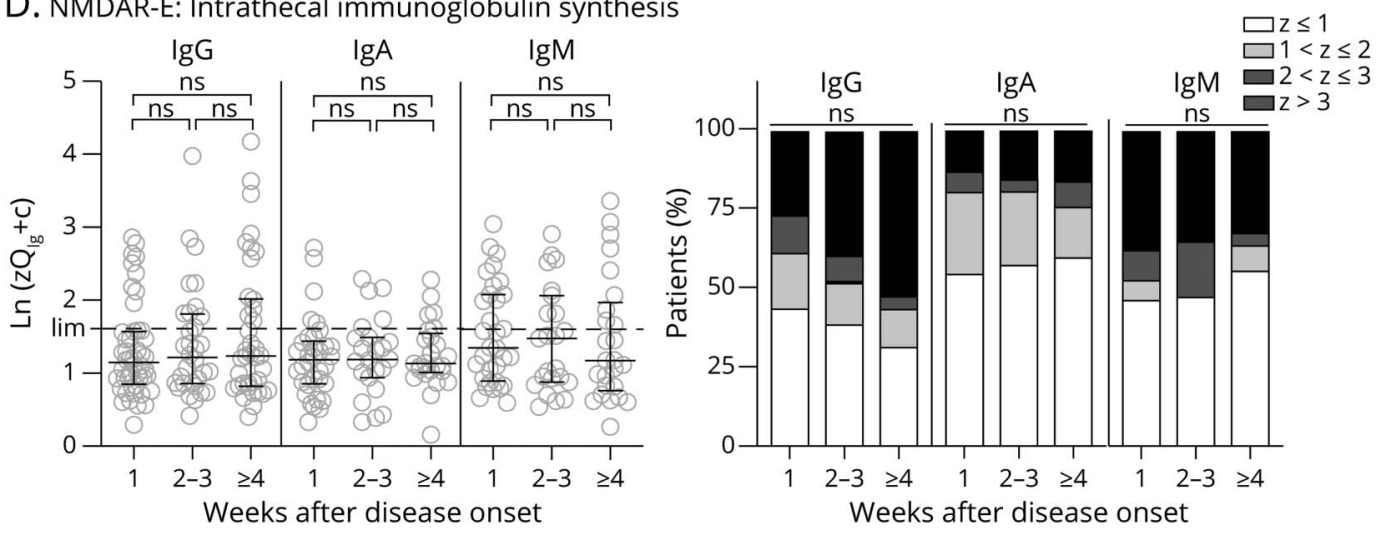

The 82 and 36 patients with therapy-naive NMDAR-E and LGI-E, respectively, were categorized with respect to the delay of lumbar puncture after onset of symptoms (week $1=$ day $0-6$; weeks $1 / 3=$ day $7-20 ; \geq 4=$ day 21 and later). CSF leukocyte count, blood-CSF barrier function, and the presence of OCB are depicted as in Figure 2, A-C and quantitative intrathecal IgG, IgA, and IgM synthesis as in Figure 3, A and B. The upper normal limits (lim, cell count: 4 cells/ $\mu$ L, $\mathrm{Q}_{\text {Alb }} / \mathrm{Q}_{\text {lim }}$ : 1.0, Q $\mathrm{g}$ : Qmean +3 SD/Z score = 3, lim) are indicated as dashed lines. Statistical analysis was performed using the Kruskal-Wallis test followed by the Dunn multiple comparisons test (A/B/D), the $\chi^{2}$ test of the unnormalized number of patients with and without OCB (C), or with or without intrathecal immunoglobulin synthesis of a Z score $>3$. ns = not significant and ${ }^{*} p<0.05$ (additional analyses in eFigures $12-14$, links.Iww.com/NXI/A600). IIS $=$ immunoglobulin synthesis; LGI1-E = leucine-rich glioma-inactivated protein 1; NMDAR-E = NMDA receptor.

Definitively inflammatory CSF can be most clearly defined as CSF with either pleocytosis or OCBs or both. In NMDAR-E, inflammatory CSF became less frequent with age (eFigure 16C, links.lww.com/NXI/A600). Only 58\% (7/12) of patients with NMDAR-E aged $>60$ years showed inflammatory CSF compared with $94 \%(66 / 70)$ younger than 60 years (Fisher exact test, $p<0.01)$. In LGI1-E, only a trend toward less frequent inflammatory CSF with age was found ( $\leq 70$ years; $9 / 26,35 \%$, vs $>70$ years: $1 / 10,10 \%$, Fisher exact test, $p=0.23$; eFigure $16 \mathrm{C}$, links.lww.com/NXI/A600). To exclude a major bias in CSF findings between NMDAR-E and LGI1-E because of the different ages of the cohorts, a subgroup analysis with patients with NMDAR- and LGI1-E aged $>40$ years was performed. The 2 groups were identical in age and sex distribution and the duration from disease onset to LP (eFigure 17, A-D, links.lww.com/ $\mathrm{NXI} / \mathrm{A} 600$ ). In patients aged $>40$ years, NMDAR-E still showed more pronounced inflammatory CSF changes (eFigure 17, E-I, links.lww.com/NXI/A600). In contrast, sex did not significantly affect CSF findings in either AE subtype (eFigure 18, links.lww. com/NXI/A600).

\section{Intrathecal Ig Synthesis Is Associated With More Severe Functional Impairment in NMDAR-E But Not in LGI1-E}

Patients with NMDAR-E with an mRS score of 0-2 showed less inflammatory CSF changes than those with mRS scores of 3 or more. However, inflammatory changes in those patients with mRS scores of 4 and 5 did not differ from those with scores of 3 (eFigure 19, links.lww.com/NXI/A600). Thus, patients were dichotomized accordingly with mRS scores $<3$ considered mild and $\geq 3$ severe functional impairment. Age, sex distribution, and duration from onset to LP were similar in the resulting subcohorts for both $\mathrm{AE}$ subtypes (eFigure 20, A-C, links.lww.com/NXI/A600). CSF leukocytes were nonsignificantly higher in severe compared with mild NMDAR-E (mRS score $\geq 3$ : median 19 cells $/ \mu \mathrm{L}$, IQR 7-63 cells $/ \mu \mathrm{L}$; mRS score $<3$ : median 7 cells $/ \mu \mathrm{L}$, IQR $6.0-15$ cells/ $\mu \mathrm{L}$; Mann-Whitney $U$ test $p=0.08$; Figure $5 \mathrm{~A}$, left graphs). Negative OCBs were almost 3 -fold more frequent in mild compared with severe disease $(64 \%, 7 / 11$, vs $23 \%, 16 /$ 71 , Fisher exact test, $p<0.01$, Figure 5C, left graphs). Z scores 
Figure 4 With Increasing Age, Patients With NMDAR-E Become Less Likely to Show CSF Pleocytosis and Quantitative Intrathecal Immunoglobulin Synthesis, Whereas Blood-CSF Barrier Dysfunction Occurs More Frequently


D. NMDAR-E: Intrathecal immunoglobulin synthesis
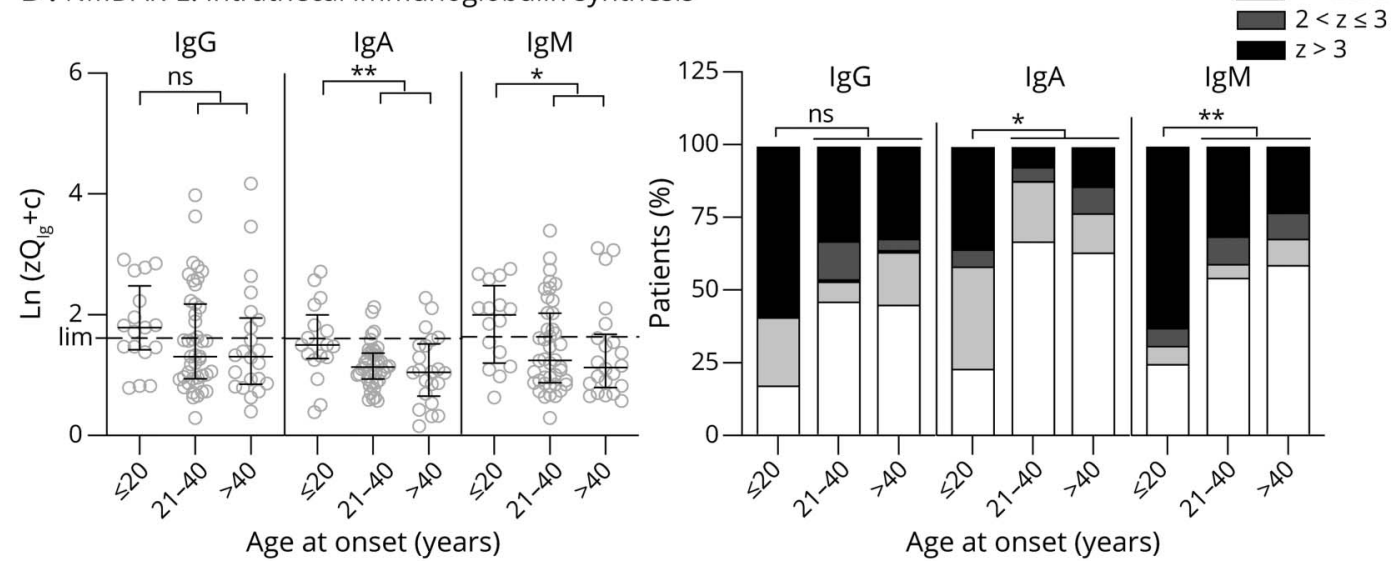

Patients with NMDAR-E were divided into 3 groups, those with the age of 20 years or younger ( $\leq 20$ years), those older than 40 years ( $>40$ years), and those in between (21-40 years). CSF leukocyte count and frequency of pleocytosis (A), blood-CSF barrier function (B), and the presence of OCB restricted to the CSF (C) are presented as in Figure 2, A-C, but only for NMDAR-E, intrathecal IgG, IgA, and IgM synthesis (D) IIS presented as in Figure 3D. Statistical analysis was performed using the Kruskal-Wallis test followed by the Dunn multiple comparisons test (A/B/D, left panels). For intrathecal immunoglobulin synthesis, patients with a Z score $>3$ were compared with those $\leq 3$. When comparing all 3 groups (B, right panel, C, D right panel IgG and IgM), the $\chi^{2}$ test of the unnormalized number of patients was performed. If the criteria for a valid $\chi^{2}$ test were not met, 2 groups were combined, and a Fisher exact test was performed (A, right panel, D right panel-IgA). ns = not significant, ${ }^{*} p<0.05, * * p<0.01$, and $* \star *$ p $<0.001$ (additional analyses including age dependency of CSF findings in LGI-E can be found in eFigures 15-18, links.IwW.com/NXI/A600). NMDAR-E = NMDA receptor.

for quantitative IgG, IgA, and IgM IIS were moderately but significantly higher in NMDAR-E with $\mathrm{mRS}$ score $\geq 3$ (Figure 5D, left graphs). Definitive quantitative IIS $(\mathrm{Z}>3)$ was significantly more frequent at $\mathrm{mRS}$ score $\geq 3$ for only IgM (Figure 5D, right graphs). In LGI1-E, no associations between CSF findings and functional impairment were found (Figure 5, A-C, right graphs, eFigure 20D, links.lww.com/ NXI/A600).

\section{Comprehensively Analyzing the Interdependency of Inflammatory CSF Parameters Among Themselves and With Relevant Confounders Identifies Disease- Specific Patterns}

For a more comprehensive description of the mutual interactions among CSF parameters, multiple models were calculated (eTable 1-5, links.lww.com/NXI/A600). These took into account the influences of disease duration and severity as well as age. Quantitative IIS was present only in NMDAR-E. Among CSF leukocytes, blood-CSF barrier function, and OCBs, only leukocytes distinguished between NMDAR-E and LGI1-E. Age was identified as a relevant confounder (eTable 2, links.lww.com/NXI/A600). Using CSF leukocytes, blood-CSF barrier function, and OCBs as target variables for LGI1-E and all 3 in addition to quantitative IgG, IgA, and IgM IIS for NMDAR-E, our multiple models largely confirmed the univariate analyses (eTables 2-5, links.lww. com/NXI/A600 Figure 6). A strong positive association of CSF leukocytes with IIS, either qualitative as OCB or quantitative, proved to be characteristic for NMDAR-E. For LGI1E, more disturbed blood-CSF barrier function remained associated with higher CSF leukocytes. In NMDAR-E, disease duration, age, and functional impairment influenced CSF findings in a characteristic manner: shorter disease duration was associated with higher CSF leukocytes, longer disease duration with a relative increase in IgG IIS and older age with 
Figure 5 In NMDAR-E, the Presence of CSF-Specific OCBs and Increased Quantitative IIS for IgG, IgA, and IgM Are the Only CSF Finding Associated With Disease Severity at the Time Point of Lumbar Puncture
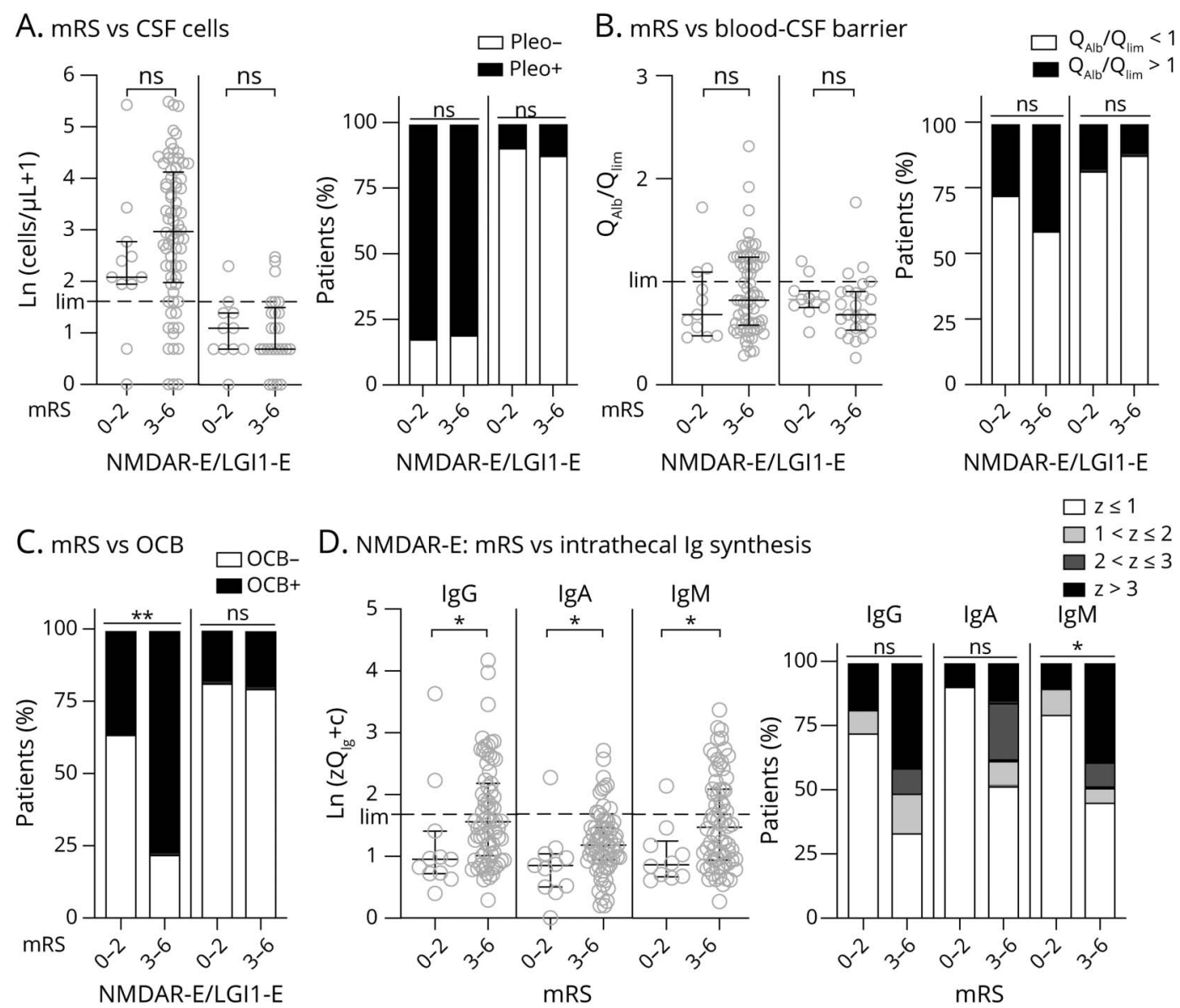

Patients with NMDAR-E and LGI1-E were dichotomized according to the degree of functional impairment using the mRS, with a score of 0-2 regarded as a low degree of impairment and 3-6 as a high degree of impairment ( $6=$ death did not occur before lumbar puncture, eFigure 19, links.Iww.com/NXI/A600). CSF leukocyte count and frequency of pleocytosis (A), age-adjusted blood-CSF barrier function (QAlb $/ Q_{\text {lim }}$ ) (B), frequency of OCBs restricted to the CSF (C), and the probability of quantitative intrathecal immunoglobulin synthesis (D) are presented as in Figure 2, A-C for A-C and in Figure 3, A and B for D. Statistical analysis was performed using the Mann-Whitney $U$ test (A/B/D, left panels) and the Fisher exact test (A/B/D right panels). For intrathecal immunoglobulin synthesis, patients with a Z score $>3$ were compared with those $\leq 3$. ns = not significant, $* p<0.05$, and $* *$ p $<0.01$ (additional analyses can be found in eFigure 19 , links. Iww. com/NXI/A600). LGI1-E = leucine-rich glioma-inactivated protein 1; mRS = modified Rankin Scale; NMDAR-E = NMDA receptor.

lower CSF leukocytes and less IgA and IgM IIS. Finally, OCB positivity was strongly associated with severe functional impairment. In LGI1-E, older age was associated with a less perturbed blood-CSF barrier. An opposite association was found for NMDAR-E.

\section{Discussion}

NMDAR- and LGI1-E are the 2 most common AE subtypes. Each is representative of 1 of 2 clusters of AE subtypes: NMDAR-E for those with prominent CSF inflammation and LGI1-E for those with little or no CSF inflammation. ${ }^{4}$ Beyond the expected quantitative differences, our detailed analysis of CSF findings in therapy-naive acute NMDAR- and LGI1-E shows that each of the $2 \mathrm{AE}$ subtype exhibits a distinct pattern of CSF changes. These are characterized by differences in the interdependencies of CSF parameters and their association with age, disease duration, and disease severity.
On the quantitative level, NMDAR-E showed $\sim 10$-fold higher CSF leukocyte counts as compared with LGI-E patients. BloodCSF barrier dysfunction and CSF-restricted OCBs occurred $\sim 2$ - and $\sim 3$-fold more frequently in NMDAR-E, respectively. Completely normal CSF was exceptional in patients with NMDAR-E (5\%) but observed in $~ 2 / 3$ of patients with LGI1E. This is in line with previous findings. ${ }^{42-15}$ We could also confirm that NMDAR-E frequently shows quantitative IIS for $\operatorname{IgG}^{16}$ and report here that IgM (35\%) and IgA (15\%) IIS are commonly present. In contrast, quantitatively relevant IIS is absent in LGI1-E.

With regard to the disease-specific mutual interactions of CSF parameters, in NMDAR-E, but not in LGI1-E, CSF leukocytes were higher when OCBs were present. In the early phase of the disease, higher CSF leukocytes were associated with more pronounced quantitative IIS, especially with IgM. These associations were absent in LGI1-E. In NMDAR-E, CSF 
Figure 6 Comprehensive Summary of Results Shows the Profound Differences in the Interdependency of Inflammatory CSF Parameters Among Each Other and Clinically Overt Disease Duration, Age at Onset, and Disease Severity in NMDAR-E and LGI1-E
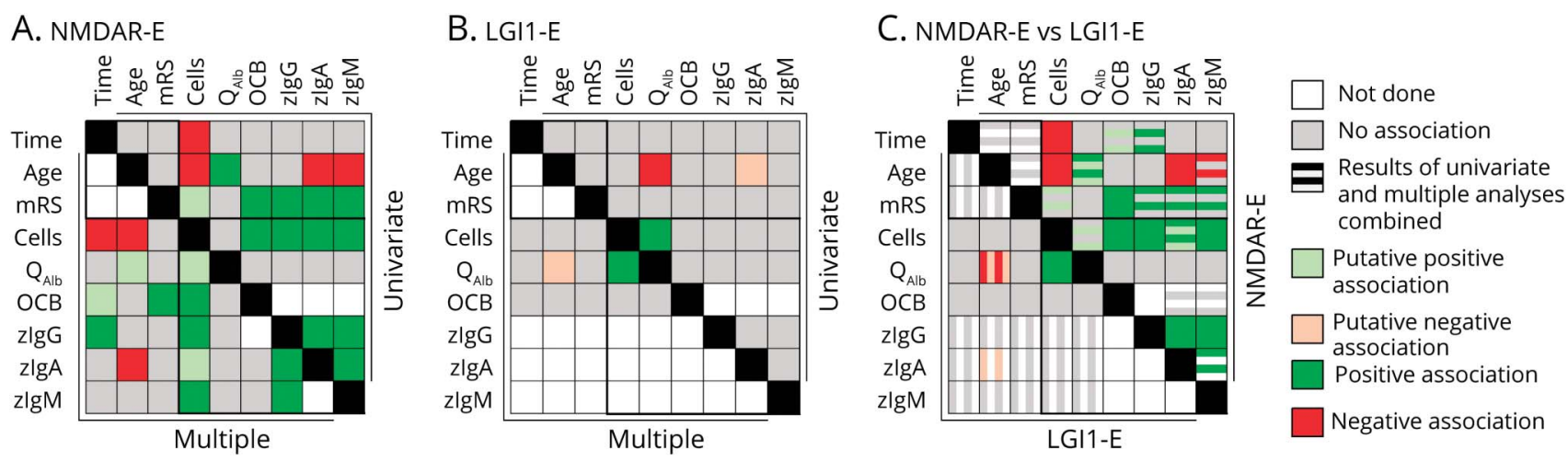

Graphical summary of all analyses. Details of the multiple analyses can be found in eTables 2-6, links.Iww.com/NXI/A600. Results of the univariate (upper right halves) and multiple analyses (lower left halves) for (A) NMDAR-E and (B) LGI1-E. The variables are indicated at the top or left of the graphs. Age $=$ age at LP; Time = time from clinical onset to LP; Cells = CSF leukocyte count; $\mathrm{Q}_{\mathrm{Alb}}=\mathrm{CSF} / \mathrm{serum}$ albumin ratio; zlgG/A/M = z SCores for IgG/A/M as a marker for quantitative intrathecal immunoglobulin synthesis. Each square summarized the results of the interaction of the 2 variables, which are color coded as indicated. Positive associations indicate significant results in at least 1 univariate analysis and a $p<0.05$ in the multiple models. Putative associations were defined either as significant results with questionable relevance (LGI1-E: age vs zIgA in the absence of relevant quantitative synthesis of IgA) or as comparisons with $p$ values $<0.1$ but not $p<0.05$. (C) Synopsis of the results of combined univariate and multiple analyses for NMDAR-E (upper right half) and LGI1-E (lower left half). Color-coded results of the univariate analysis can be found as the uppermost and third stripe in each box for NMDAR-E and the left and third from the left strip in each box for LGI1-E. Boxes comparing 1 variable with itself are blackened. Comparison of the 3 confounders with each other or the different CSF parameters are indicated by 2 black frames. LGI1-E = leucine-rich glioma-inactivated protein 1; LP = lumbar puncture; mRS = modified Rankin Scale score at LP; NMDAR-E = NMDA receptor; OCB = oligoclonal bands restricted to the CSF.

pleocytosis might thus be a surrogate marker for a factor that, at least in the acute phase, boosts IIS, e.g., like the B cellattracting chemokine $\mathrm{C}-\mathrm{X}-\mathrm{C}$ motif chemokine 13 , which is associated with the intrathecal synthesis of NMDAR-specific IgG in NMDAR-E. ${ }^{17}$ However, even in infectious diseases of the CNS, only $10-20 \%$ of intrathecally synthesized IgG is pathogen-specific. ${ }^{18}$ Thus, only a fraction of the total IgG quantitative IIS described herein can be expected to be NMDAR-specific IgG. The extent of intrathecal antiNMDAR-IgG synthesis neither correlated with the extent of intrathecal synthesis of total IgG nor had NMDAR-E patients with positive OCB more NMDAR-specific IIS than those without. This indicates that total and the NMDAR-specific IgG synthesis in the CSF compartment are regulated quite differently in NMDAR-E. Our results also show that later in the course of NMDAR-E, IIS becomes independent of CSF leukocytes. In NMDAR-E brains, antibody-secreting cells reside in perivascular, interstitial, and Virchow-Robin spaces, ${ }^{19}$ which may be the source of the continuously synthesized Ig. In contrast to NMDAR-E, CSF leukocytes were strongly associated with blood-CSF barrier dysfunction in LGI1-E. It has been hypothesized that in LGI1-E, systemically synthesized anti-LGI1-IgG and complement from plasma enter the brain at sites of blood-barrier dysfunction, where both will induce focal inflammation. ${ }^{20,21}$ Although the bloodCSF barrier is not completely identical to the blood-brain barrier, we find that a relative increase in a major plasma protein, albumin, in the LGI1-E CSF is associated with cellular signs of inflammation. Thus, our findings might reflect and support the presumed pathophysiology of LGI-E with proteins from the systemic circulation that enter the intrathecal space playing an important role in the induction of inflammation.

Patient-specific confounders such as age, disease duration, and severity also differentially affect the CSF findings in NMDAR- and LGI1-E. In NMDAR-E, but not in LGI1-E, CSF leukocyte counts become lower with longer disease duration and older age. Higher CSF leukocytes in NMDAR-E very early after onset as compared with later time points have been reported previously. ${ }^{15}$ Blood-CSF barrier dysfunction became more prominent in older patients with NMDAR-E but was less prominent in older patients with LGI1-E. Although $\mathrm{OCB}$ occurred $\sim 2$-fold less frequently in mild NMDAR-E, clinical severity in LGI1-E was independent of the presence or absence of OCB. In NMDAR-E, older age seems to dampen the IIS for IgM and even more so for IgA.

We have already reported that $\mathrm{AE}$ subtypes that typically manifest at older age show less CSF inflammation. ${ }^{4}$ Here, we show that even in patients with the same antibody-defined $\mathrm{AE}$ subtype, NMDAR-E, advanced age decreases the likelihood of inflammatory CSF findings, possibly a result of immune senescence. $^{22}$ Thus, normal routine CSF findings should not preclude testing for antineuronal antibodies in the elderly when $\mathrm{AE}$ is suspected.

Our findings are in contrast to previous reports that OCBs rarely occur in early NMDAR-E and become more frequent with time. ${ }^{15}$ In our cohort, OCBs were positive in almost $2 / 3$ of patients with NMDAR-E, even within the first week, compared with $<10 \%$ at first LP in the previous study. ${ }^{15}$ 
Moreover, positive OCBs did not become significantly more frequent at later time points in both $\mathrm{AE}$ subtypes studied. The reason for these discrepancies remains unknown, and they might result from different methods applied for OCB detection. However, our results of frequently positive OCBs in very early NMDAR-E are confirmed by quantitative IIS in $40 \%$ of patients within the first 3 days after clinical onset. In Herpes simplex virus encephalitis, quantitative IIS was found in only $10 \%$ of patients within the first week after onset. ${ }^{23}$ Considering the slow pace at which quantitative IIS develops in pathogen-induced encephalitis, we conclude that the presence of quantitative IIS in NMDAR-E most likely precedes clinical onset of $\mathrm{AE}$ in a relevant proportion of cases.

As the pattern of quantitative IIS ( $\operatorname{IgG}>\operatorname{IgM}>>\operatorname{IgA}$ ) in NMDAR-E resembled MS, ${ }^{8,24}$ we tested for polyspecific immune activation (aka MRZ reaction) in NMDAR-E CSF. The MRZ reaction is positive in $\sim 75 \%$ of patients with $M S .{ }^{25,26} \mathrm{In}$ addition, the MRZ reaction is regarded as highly specific for $\mathrm{MS}^{25,26}$ The MRZ reaction is believed to evolve in a chronically inflamed CNS when circulating plasmablasts/plasma cells are unspecifically recruited to niches for survival and expansion over time. ${ }^{27,28} \mathrm{MRZ}$ positivity in our subcohort of patients with NMDAR-E $(>1 / 3)$ proved to be the highest among any neurologic disease besides MS. ${ }^{26}$ In addition to the robust early quantitative IIS, this finding supports the hypothesis of a preexisting MS-like inflammatory CNS process in some NMDAR-E cases. Of note, white matter lesions in patients with NMDAR-E suggestive of demyelination are frequently found in NMDAR-E. ${ }^{1,29}$ Even symptomatic episodes of demyelination have been reported. However, those were mostly associated with aquaporin-4 (AQP4) and myelin oligodendrocyte protein (MOG) antibodies. ${ }^{30}$ Regardless of symptomatic demyelination, AQP4 and MOG antibodies occur in $4 \%$ of patients with NMDAR-E. ${ }^{31}$ Of note, the MRZ reaction is typically negative in AQP4 and MOG antibodyassociated demyelinating diseases. ${ }^{25,26}$ In our NMDAR-E subcohort, the frequency of MRZ positivity was 10-fold higher that the reported frequency of AQP4 and MOG antibodies. ${ }^{32}$ In addition, single cases of NMDAR-E coexisting with MS have been reported. ${ }^{33-35}$ Thus, the immunologic and clinical commonalities of NMDAR-E and MS may be more relevant than those with AQP4 and MOG antibodyassociated demyelinating diseases and require further investigation.

Nevertheless, our results should be interpreted with caution because of the retrospective and cross-sectional nature of the present study and the limited number of patients included, especially for testing the MRZ reaction. However, we could not detect any relevant selection bias of the patients characterized in detail compared with the total population in GENERATE. We estimate biases due to laboratory imprecisions as a result of including local laboratory analyses to be minor because no OCB-negative cases with quantitative IIS according to the Reiber formulas occurred. Still, at low $\mathrm{Q}_{\mathrm{Alb}} \mathrm{S}$, the corresponding $\mathrm{Z}$ scores had to be adjusted. However, alternatively to analytical imprecision at low CSF IgG/M values, this might hint at a more general phenomenon, as similar observations have been reported. ${ }^{36}$ Taken together, these observations suggest the possibility that at low $\mathrm{Q}_{\mathrm{Alb}} \mathrm{s}$, the Reiber formulas tend to result in slightly too low $\mathrm{Q}_{\text {mean }} \mathrm{s}$ for IgG and IgM. However, studies with larger cohorts are needed to confirm this assumption. Still, the Reiber formulas are much better than other formulas for IIS reference values because those only define upper normal limits ${ }^{36-38}$ and are thus not suitable to calculate $\mathrm{Z}$ scores.

In summary, we show that NMDAR-E and LGI1-E show very different CSF patterns on detailed analysis, indicating divergent immunopathogeneses. We present evidence for a more chronic inflammatory response in NMDAR-E with robust quantitative IIS and frequently positive polyspecific immune activation, presumably preceding clinical onset. In addition, our finding that higher CSF leukocytes are associated with more pronounced quantitative IIS in the hyperacute phase of encephalitis but not at later stages when CSF leukocytes decrease while IIS persists indicates that the acute inflammation during onset of encephalitis transiently triggers the more long-lasting quantitative IIS before or soon after the clinical manifestation of encephalitis. CSF leukocyte counts and blood-CSF barrier dysfunction have been reported to be of prognostic value in NMDAR-E. ${ }^{39,40}$ Future studies are needed to investigate whether including quantitative IgG, IgA, and IgM IIS may refine the prognostic relevance of CSF in NMDAR-E. With regard to diagnostic decisions, we show that the presence of quantitative IIS and/ or pleocytosis $>50$ cells $/ \mu \mathrm{L}$ makes that diagnosis of LGI-E highly unlikely. Finally, our study shows that in the 2 most common AE subtypes, inflammatory CSF becomes less frequent in elderly patients. This is explained by not only the older age of patients with LGI-E with their frequently normal CSF but also a decreased frequency of inflammatory CSF in older patients with NMDAR-E. This important information warrants that noninflammatory CSF in elderly patients with clinically possible AE should not lead to an omission of antibody testing.

\section{Acknowledgment}

This work was supported by members of the GENERATE network, who contributed to patient recruitment and data acquisition and entry. All members of the GENERATE network as of September 2020 are indicated in the Appendix. The authors are indebted to all active and associated members of the GENERATE network and especially to patients and relatives willing to support this research. They thank Pamela Maher, $\mathrm{PhD}$, for the critical reading of the manuscript.

\section{Study Funding}

This study was supported by the German Federal Ministry of Education and Research (BMBF) through a grant Forschungsverbund CONNECT-GENERATE, grant codes 01GM1908A and 01GM1908C. 


\section{Disclosure}

M. Dürr, G. Nissen, M. Kaufmann, M. Madlener, K.-P. Wandinger, C. Kellinghaus, J. Dreyhaupt, M.G. Häusler, and H. Schneider and P. Lange report no conflict of interest. K.-W. Sühs received honoraria from Merck, Celgene, UCB Pharma, and Alexion, all outside the submitted work. P. Schwenkenbecher received travel compensation and congress fee from Merck-Serono. C. Geis received speaker honoraria from Roche and Alexion and travel reimbursement from Merck. His research is funded by German Federal Ministry of Education and Research (BMBF) through a grant Forschungsverbund CONNECT-GENERATE, grant codes 01GM1908B and 01GM1908E, the Schilling Foundation, and Deutsche Forschungsgemeinschaft (DFG, GE2519/9-1, GE2519/8-1). M. Ringelstein received speaker honoraria from Novartis, Bayer Vital GmbH, Roche, Alexion, and Ipsen and travel reimbursement from Bayer Schering, Biogen Idec, Merz, Genzyme, Teva, Roche, and Merck, none related to this study. H.-P. Hartung has received honoraria for serving on steering and data monitoring committees from Bayer, Biogen, GeNeuro, Merck, Novartis, Roche, Sanofi Genzyme, and TG Therapeutics, with approval by the Rector of HHU. M.A. Friese received speaker honoraria from Biogen, Merck, Novartis, and Roche, none related to this study. His research is funded by the German Federal Ministry of Education and Research (BMBF), Deutsche Forschungsgesellschaft (DFG), Hamburg Ministry of Science and Research, Fritz Thyssen Stiftung, Gemeinnützige Hertie-Stiftung, Else KrönerFresenius-Stiftung, Werner Otto Stiftung, and Stifterverband, outside the submitted work. M. P. Malter has received honoraria for lectures and consultancies from UCB Pharma and EISAI GmbH. FT received grant support from Novartis. T. Kümpfel has received speaker honoraria and/or personal fees for advisory boards from Bayer HealthCare, Teva Pharma, Merck, Novartis Pharma, Sanofi-Aventis/Genzyme, Roche Pharma, and Biogen and grant support from Novartis and Chugai Pharma in the past. MS has received consulting and/or speaker honoraria from Alexion, Bayer, Biogen, Merck, Roche, and Sanofi Genzyme. She has received travel support from Celgene and Teva. She has received research funding from the Hertha-Nathorff-Program. F.T. Bergh received speaker honoraria from Actelion, Alexion, Bayer, Biogen, Genzyme, Merck-Serono, Novartis, Roche, and Teva; travel reimbursement to attend scientific meetings from Bayer, Biogen, Genzyme, Merck-Serono, Novartis, Roche, and Teva; research support for investigator-initiated studies, through his institution, from the German Research Foundation (DFG), the German Federal Ministry of Education and Research (BMBF), Actelion, Bayer, MerckSerono, Novartis, and Teva; none of these funds were related to this study. U. K. Zettl received speaker fees, travel compensation and/or his section received support from Alexion, Almirall, Bayer, Biogen, Celgene, Genzyme, Merck-Serono, Novartis, Roche, Sanofi-Aventis, and Teva. His research is funded by the German Ministry for Education and Research (BMBF), German Ministry of Economy (BMWi), Deutsche
Forschungsgesellschaft (DFG), and European Union (EU), outside the submitted work. N. Melzer received honoraria for lecturing and travel expenses for attending meetings from Biogen Idec, GlaxoSmithKline, Teva, Novartis Pharma, Bayer HealthCare, Genzyme, Alexion Pharmaceuticals, Fresenius Medical Care, Diamed, and BIAL and has received financial research support from Euroimmun, Fresenius Medical Care, Diamed, Alexion Pharamceuticals, and Novartis Pharma. C.C. Gross received speaker honoraria from Mylan, Bayer HealthCare, and Sanofi-Genzyme and travel/accommodation/ meeting expenses from Bayer HealthCare, Biogen, Euroimmun, Novartis, and Sanofi-Genzyme. She also received research support from Biogen and Novartis. H. Tumani reports funding for research projects, lectures, and travel from Alexion, Bayer, Biogen, Celgene, Genzyme, Fresenius, Merck, Mylan, Novartis, Roche, Siemens Health Diagnostics, and Teva and received research support from DMSG and German Federal Ministry of Education and Research (BMBF). F. Leypoldt received speaker fees and travel compensation and serves on advisory boards for/from Alexion, Bayer, Biogen, Fresenius, Merck-Serono, Novartis, Roche, and Teva. His research is funded by the German Federal Ministry of Education and Research (BMBF) and Deutsche Forschungsgesellschaft (DFG) and European Union (EU), outside the submitted work. He works for an academic institution, which also offers commercial antibody testing. J. Lewerenz received speaker fees or travel compensation from UCB, Bayer, Roche, Teva, and the Cure Huntington's Disease Initiative (CHDI). His institution has been reimbursed for his role as a principal investigator in trials for UCB and CHDI. His research is funded by the European Huntington's Disease Initiative and Ministry for Education and Research Baden-Württemberg, outside the submitted work, and the German Federal Ministry of Education and Research (BMBF). He works for an academic institution, which also offers commercial antibody testing.

\section{Publication History}

Received by Neurology: Neuroimmunology \& Neuroinflammation April 19, 2021. Accepted in final form August 24, 2021.

Appendix 1 Authors

\begin{tabular}{lll}
\hline Name & Location & Contribution \\
\hline Marc Dürr & $\begin{array}{l}\text { Department of } \\
\text { Neurology, Ulm } \\
\text { University; Department } \\
\text { of Neurosurgery, } \\
\text { University Hospital } \\
\text { Tübingen, Germany }\end{array}$ & $\begin{array}{l}\text { Drafting/revision of the } \\
\text { manuscript for content, } \\
\text { including medical writing } \\
\text { for content; major role in } \\
\text { the acquisition of data; } \\
\text { study concept or design; } \\
\text { and analysis or } \\
\text { interpretation of data }\end{array}$ \\
& & $\begin{array}{l}\text { Drafting/revision of the } \\
\text { manuscript for content, }\end{array}$ \\
& $\begin{array}{l}\text { Neuroimmunology, } \\
\text { Institute of Clinical } \\
\text { Gunnar Nissen } \\
\text { Chemistry, University medical writing } \\
\text { Hospital Schleswig- } \\
\text { Holstein Kiel/Lübeck, } \\
\text { Germany }\end{array}$ & $\begin{array}{l}\text { role in the acquisition of } \\
\text { data }\end{array}$ \\
& &
\end{tabular}


Appendix 1 (continued)

\begin{tabular}{lll}
\hline Name & Location & Contribution \\
\hline $\begin{array}{l}\text { Kurt-Wolfram Sühs, } \\
\text { MD }\end{array}$ & $\begin{array}{l}\text { Department of } \\
\text { Neurology, Hannover } \\
\text { Medical School, }\end{array}$ & $\begin{array}{l}\text { Drafting/revision of the } \\
\text { manuscript for content, } \\
\text { including medical writing } \\
\text { Germany }\end{array}$ \\
& $\begin{array}{l}\text { for content, and } \\
\text { additional contributions: } \\
\text { acquisition of some of } \\
\text { the data }\end{array}$
\end{tabular}

\begin{tabular}{ll}
\hline Philipp & Department of \\
Schwenkenbecher, & Neurology, Hannover \\
MD & Medical School, \\
& Germany
\end{tabular}

Drafting/revision of the manuscript for content including medical writing for content, and additional contributions: acquisition of some of the data

\begin{aligned} \hline Christian Geis, MD & Department of \\ & Neurology, University \\ & Hospital Jena, Germany \end{aligned}

Drafting/revision of the manuscript for content, including medical writing for content, and additional contributions: acquisition of some of the data

\begin{tabular}{ll}
\hline Marius Ringelstein, & Department of \\
MD & Neurology, Medical \\
& Faculty, Heinrich Heine \\
& University Düsseldorf; \\
& Department of \\
& Neurology, Center for \\
& Neurology and \\
& Neuropsychiatry, LVR- \\
& Klinikum Düsseldorf, \\
& Germany
\end{tabular}

Drafting/revision of the manuscript for content, including medical writing for content, and additional contributions: acquisition of some of the data

\begin{tabular}{ll}
\hline Hans-Peter & Department of \\
Hartung, MD & Neurology, Medical \\
& Faculty, Heinrich Heine \\
& University Düsseldorf, \\
& Germany
\end{tabular}

Manuel A. Friese, MD

Institute of
Neuroimmunology and
multiple sclerosis,
University Medical
Center Hamburg-
Eppendorf, Germany

Drafting/revision of the manuscript for content, including medical writing for content, and additional contributions: acquisition of some of the data

Drafting/revision of the manuscript for content including medical writing for content, and additional contributions: acquisition of some of the data

Max Kaufmann, MD Institute of Neuroimmunology and multiple sclerosis, University Medica Center HamburgEppendorf, Germany

Drafting/revision of the manuscript for content, including medical writing for content, and additional contributions: acquisition of some of the data

\begin{tabular}{lll}
\hline $\begin{array}{l}\text { Michael P. Malter, } \\
\text { MD }\end{array}$ & $\begin{array}{l}\text { Department of } \\
\text { Neurology, University of } \\
\text { Cologne, Faculty of } \\
\text { Medicine and University } \\
\text { Hospital, Germany }\end{array}$ & $\begin{array}{l}\text { Drafting/revision of the } \\
\text { manuscript for content, } \\
\text { including medical writing } \\
\text { for content, and } \\
\text { additional contributions: } \\
\text { acquisition of some of } \\
\text { the data }\end{array}$ \\
\hline Marie Madlener, & $\begin{array}{l}\text { Department of } \\
\text { Neurology, University of } \\
\text { Cologne, Faculty of } \\
\text { Medicine and University } \\
\text { Hospital, Germany }\end{array}$ & $\begin{array}{l}\text { Drafting/revision of the } \\
\text { manuscript for content, } \\
\text { including medical writing } \\
\text { for content, and } \\
\text { additional contributions: } \\
\text { acquisition of some of } \\
\text { the data }\end{array}$ \\
& & and
\end{tabular}

Appendix 1 (continued)

\begin{tabular}{|c|c|c|}
\hline Name & Location & Contribution \\
\hline $\begin{array}{l}\text { Franziska S Thaler, } \\
\text { MD }\end{array}$ & $\begin{array}{l}\text { Institute of clinical } \\
\text { Neuroimmunology, } \\
\text { University Hospital and } \\
\text { Biomedical Center, } \\
\text { Ludwig-Maximilians } \\
\text { University Munich, } \\
\text { Germany }\end{array}$ & $\begin{array}{l}\text { Drafting/revision of the } \\
\text { manuscript for content, } \\
\text { including medical writing } \\
\text { for content, and additional } \\
\text { contributions: acquisition } \\
\text { of some of the data }\end{array}$ \\
\hline Tania Kümpfel, MD & $\begin{array}{l}\text { Institute of clinical } \\
\text { Neuroimmunology, } \\
\text { University Hospital and } \\
\text { Biomedical Center, } \\
\text { Ludwig-Maximilians } \\
\text { University Munich, } \\
\text { Germany }\end{array}$ & $\begin{array}{l}\text { Drafting/revision of the } \\
\text { manuscript for content, } \\
\text { including medical writing } \\
\text { for content, and additional } \\
\text { contributions: acquisition } \\
\text { of some of the data }\end{array}$ \\
\hline Makbule Senel, MD & $\begin{array}{l}\text { Department of } \\
\text { Neurology, Ulm } \\
\text { University, Germany }\end{array}$ & $\begin{array}{l}\text { Drafting/revision of the } \\
\text { manuscript for content, } \\
\text { including medical writing } \\
\text { for content, and additional } \\
\text { contributions: acquisition } \\
\text { of some of the data }\end{array}$ \\
\hline $\begin{array}{l}\text { Martin G. Häusler, } \\
\text { MD }\end{array}$ & $\begin{array}{l}\text { Department of } \\
\text { Pediatrics, University } \\
\text { Hospital RWTH Aachen, } \\
\text { Germany }\end{array}$ & $\begin{array}{l}\text { Drafting/revision of the } \\
\text { manuscript for content, } \\
\text { including medical writing } \\
\text { for content, and additional } \\
\text { contributions: acquisition } \\
\text { of some of the data }\end{array}$ \\
\hline
\end{tabular}

\begin{tabular}{lll}
\hline Hauke Schneider, & Technische Universität & Drafting/revision of the \\
MD & Dresden, and & manuscript for content, \\
Department of & including medical writing \\
& $\begin{array}{l}\text { Neurology, University } \\
\text { Hospital Augsburg, }\end{array}$ & for content, and additional \\
Germany & contributions: acquisition \\
& of some of the data
\end{tabular}

Florian Then Bergh, Department of

MD Neurology, University

Drafting/revision of the manuscript for content, including medical writing Germany for content, and additional contributions: acquisition of some of the data

\begin{tabular}{ll}
\hline Christoph & Department of \\
Kellinghaus, MD & Neurology, Klinikum \\
& Osnabrück, Germany
\end{tabular}

Drafting/revision of the manuscript for content including medical writing for content, and additional contributions: acquisition of some of the data

\begin{tabular}{|c|c|c|}
\hline Uwe K. Zettl, MD & $\begin{array}{l}\text { Department of } \\
\text { Neurology, section for } \\
\text { Neuroimmunology, } \\
\text { University Hospital } \\
\text { Rostock, Germany }\end{array}$ & $\begin{array}{l}\text { Drafting/revision of the } \\
\text { manuscript for content, } \\
\text { including medical writing } \\
\text { for content, and additional } \\
\text { contributions: acquisition } \\
\text { of some of the data }\end{array}$ \\
\hline $\begin{array}{l}\text { Klaus-Peter } \\
\text { Wandinger, MD }\end{array}$ & $\begin{array}{l}\text { Neuroimmunology, } \\
\text { Institute of clinical } \\
\text { Chemistry, University } \\
\text { Hospital Schleswig- } \\
\text { Holstein Kiel/Lübeck, } \\
\text { Germany }\end{array}$ & $\begin{array}{l}\text { Drafting/revision of the } \\
\text { manuscript for content, } \\
\text { including medical writing } \\
\text { for content, and additional } \\
\text { contributions: acquisition } \\
\text { of some of the data }\end{array}$ \\
\hline Nico Melzer, MD & $\begin{array}{l}\text { Department of } \\
\text { Neurology, Medical } \\
\text { Faculty, Heinrich Heine } \\
\text { University Düsseldorf; } \\
\text { Department of } \\
\text { Neurology with Institute } \\
\text { of Translational } \\
\text { Neurology, University } \\
\text { Hospital Münster, } \\
\text { Germany }\end{array}$ & $\begin{array}{l}\text { Drafting/revision of the } \\
\text { manuscript for content, } \\
\text { including medical writing } \\
\text { for content, and } \\
\text { additional contributions: } \\
\text { acquisition of some of } \\
\text { the data }\end{array}$ \\
\hline
\end{tabular}

Continued 
Appendix 1 (continued)

\begin{tabular}{|c|c|}
\hline Name & Location \\
\hline $\begin{array}{l}\text { Catharina C. Gross, } \\
\text { PhD }\end{array}$ & $\begin{array}{l}\text { Department of } \\
\text { Neurology with Institute } \\
\text { of Translational } \\
\text { Neurology, University } \\
\text { Hospital Münster, } \\
\text { Germany }\end{array}$ \\
\hline
\end{tabular}

Peter Lange Department of Neurology, University manuscript for content, Hospital Göttingen, Germany including medical writing for content, and major role in the acquisition of data

\begin{tabular}{ll}
\hline Jens Dreyhaupt, & Department of \\
PhD & Neurology, Ulm \\
& University, Germany
\end{tabular}

Drafting/revision of the manuscript for content including medical writing for content; study concept or design; and analysis or interpretation of data

\begin{tabular}{ll}
\hline Hayrettin Tumani, & Department of \\
MD & Neurology, Ulm \\
& University, Germany
\end{tabular}

Drafting/revision of the manuscript for content, including medical writing for content, and additional contributions: acquisition of some of the data

\begin{tabular}{lll}
\hline Frank Leypoldt, MD & $\begin{array}{l}\text { Neuroimmunology, } \\
\text { Institute of Clinical } \\
\text { Chemistry, University } \\
\text { Hospital Schleswig- } \\
\text { Holstein Kiel/Lübeck; } \\
\text { Department of } \\
\text { Neurology, University } \\
\text { Hospital Schleswig- } \\
\text { Holstein and Kiel } \\
\text { University, Germany }\end{array}$ & $\begin{array}{l}\text { Drafting/revision of the } \\
\text { manuscript for content, } \\
\text { including medical writing } \\
\text { for content, and } \\
\text { additional contributions: } \\
\text { acquisition of some of } \\
\text { the data }\end{array}$ \\
\hline Jan Lewerenz, MD & $\begin{array}{l}\text { Department of } \\
\text { Neurology, Ulm } \\
\text { University, Germany }\end{array}$ & $\begin{array}{l}\text { Drafting/revision of the } \\
\text { manuscript for content, } \\
\text { including medical writing } \\
\text { for content; major role in } \\
\text { the acquisition of data; } \\
\text { study concept or design; } \\
\text { and analysis or } \\
\text { interpretation of data }\end{array}$ \\
& &
\end{tabular}

\section{Appendix 2 Coinvestigators}

Coinvestigators are listed at links.Iww.com/NXI/A640.

\section{References}

1. Granerod J, Ambrose HE, Davies NW, et al. Causes of encephalitis and differences in their clinical presentations in England: a multicentre, population-based prospective study. Lancet Infect Dis. 2010;10(12):835-44.

2. van Sonderen A, Schreurs MW, Wirtz PW, Sillevis Smitt PA, Titulaer MJ. From VGKC to LGI1 and Caspr2 encephalitis: the evolution of a disease entity over time. Autoimmun Rev. 2016;15(10):970-974.

3. Dalmau J, Lancaster E, Martinez-Hernandez E, Rosenfeld MR, Balice-Gordon R Clinical experience and laboratory investigations in patients with anti-NMDAR encephalitis. Lancet Neurol. 2011;10(1):63-74.

4. Blinder $\mathrm{T}$, Lewerenz J. Cerebrospinal fluid findings in patients with autoimmune encephalitis-A systematic analysis. Front Neurol. 2019;10:804.

5. Graus F, Titulaer MJ, Balu R, et al. A clinical approach to diagnosis of autoimmune encephalitis. Lancet Neurol. 2016;15(4):391-404.

6. Rankin J. Cerebral vascular accidents in patients over the age of 60. II. Prognosis. Scott Med J. 1957;2(5):200-215.
7. Reiber H. Flow rate of cerebrospinal fluid (CSF) - a concept common to norma blood-CSF barrier function and to dysfunction in neurological diseases. J Neurol Sci. 1994;122(2):189-203.

8. Reiber H. Cerebrospinal fluid-physiology, analysis and interpretation of protein patterns for diagnosis of neurological diseases. Mult Scler. 1998;4(3): 99-107.

9. Reiber H, Lange P. Quantification of virus-specific antibodies in cerebrospinal fluid and serum: sensitive and specific detection of antibody synthesis in brain. Clin Chem. 1991;37(7):1153-1160.

10. Schwenkenbecher $P$, Skripuletz $T$, Lange $P$, et al. Intrathecal antibody production against Epstein-Barr and other neurotropic viruses in autoimmune encephalitis Neurol Neuroimmunol Neuroinflamm. 2021;8(6):e1062.

11. Ariño H, Armangué T, Petit-Pedrol M, et al. Anti-LGI1-associated cognitive impairment: presentation and long-term outcome. Neurology. 2016;87(8):759-765.

12. Quek AM, Britton JW, McKeon A, et al. Autoimmune epilepsy: clinical characteristics and response to immunotherapy. Arch Neurol. 2012;69(5):582-593.

13. Malter MP, Frisch C, Schoene-Bake JC, et al. Outcome of limbic encephalitis with VGKC-complex antibodies: relation to antigenic specificity. J Neurol. 2014;261(9): 1695-1705.

14. Dalmau J, Gleichman AJ, Hughes EG, et al. Anti-NMDA-receptor encephalitis: case series and analysis of the effects of antibodies. Lancet Neurol. 2008;7(12): 1091-1098.

15. Irani SR, Bera K, Waters $\mathrm{P}$, et al. $\mathrm{N}$-methyl-D-aspartate antibody encephalitis: temporal progression of clinical and paraclinical observations in a predominantly nonparaneoplastic disorder of both sexes. Brain. 2010;133(Pt 6):1655-1667.

16. Wang R, Guan HZ, Ren HT, Wang W, Hong Z, Zhou D. CSF findings in patients with anti-N-methyl-D-aspartate receptor-encephalitis. Seizure. 2015;29:137-142.

17. Leypoldt F, Höftberger R, Titulaer MJ, et al. Investigations on CXCL13 in anti-N methyl-D-aspartate receptor encephalitis: a potential biomarker of treatment response. JAMA Neurol. 2015;72(2):180-186.

18. Jacobi C, Lange P, Reiber H. Quantitation of intrathecal antibodies in cerebrospinal fluid of subacute sclerosing panencephalitis, herpes simplex encephalitis and multiple sclerosis: discrimination between microorganism-driven and polyspecific immune response. J Neuroimmunol. 2007;187(1-2):139-146.

19. Martinez-Hernandez E, Horvath J, Shiloh-Malawsky Y, Sangha N, Martinez-Lage M, Dalmau J. Analysis of complement and plasma cells in the brain of patients with antiNMDAR encephalitis. Neurology. 2011;77(6):589-593.

20. Tröscher AR, Klang A, Franch M, et al. Selective limbic blood-brain barrier breakdown in a feline model of limbic encephalitis with LGI1 antibodies. Front Immunol. 2017;8:1364.

21. Klang A, Schmidt P, Kneissl S, et al. IgG and complement deposition and neuronal loss in cats and humans with epilepsy and voltage-gated potassium channel complex antibodies. J Neuropathol Exp Neurol. 2014;73(5):403-413.

22. Denkinger MD, Leins H, Schirmbeck R, Florian MC, Geiger H. HSC aging and senescent immune remodeling. Trends Immunol. 2015;36(12):815-824.

23. Fomsgaard A, Kirkby N, Jensen IP, Vestergaard BF. Routine diagnosis of herpes simplex virus (HSV) encephalitis by an internal DNA controlled HSV PCR and an IgG-capture assay for intrathecal synthesis of HSV antibodies. Clin Diagn Virol. 1998; 9(1):45-56.

24. Deisenhammer F, Zetterberg H, Fitzner B, Zettl UK. The cerebrospinal fluid in multiple sclerosis. Front Immunol. 2019;10:726.

25. Hottenrott $\mathrm{T}$, Dersch R, Berger B, et al. The intrathecal, polyspecific antiviral immune response in neurosarcoidosis, acute disseminated encephalomyelitis and autoimmune encephalitis compared to multiple sclerosis in a tertiary hospital cohort. Fluids Barriers CNS. 2015;12:27.

26. Jarius $\mathrm{S}$, Eichhorn $\mathrm{P}$, Franciotta D, et al. The MRZ reaction as a highly specific marker of multiple sclerosis: re-evaluation and structured review of the literature. J Neurol. 2017;264(3):453-466.

27. Bonnan M. Does disease-irrelevant intrathecal synthesis in multiple sclerosis make sense in the light of tertiary lymphoid organs? Front Neurol. 2014;5:27.

28. Otto C, Hofmann J, Ruprecht K. Antibody producing B lineage cells invade the central nervous system predominantly at the time of and triggered by acute EpsteinBarr virus infection: a hypothesis on the origin of intrathecal immunoglobulin synthesis in multiple sclerosis. Med Hypotheses. 2016;91:109-113.

29. Wang RJ, Chen BD, Qi D. Anti-N-methyl-D-aspartate receptor encephalitis concomitant with multifocal subcortical white matter lesions on magnetic resonance imaging: a case report and review of the literature. BMC Neurol. 2015;15:107.

30. Titulaer MJ, Höftberger R, Iizuka T, et al. Overlapping demyelinating syndromes and anti-N-methyl-D-aspartate receptor encephalitis. Ann Neurol. 2014;75(3): 411-428.

31. Martinez-Hernandez E, Guasp M, Garcia-Serra A, et al. Clinical significance of antiNMDAR concurrent with glial or neuronal surface antibodies. Neurology. 2020; 94(22):e2302-e2310

32. Baheerathan A, Brownlee WJ, Chard DT, Shields K, Gregory R, Trip SA. Antecedent anti-NMDA receptor encephalitis in two patients with multiple sclerosis. Mult Scler Relat Disord. 2017;12:20-22.

33. Fleischmann R, Prüss $\mathrm{H}$, Rosche B, et al. Severe cognitive impairment associated with intrathecal antibodies to the NR1 subunit of the N-methyl-D-aspartate receptor in a patient with multiple sclerosis. JAMA Neurol. 2015;72(1):96-99.

34. Gulec B, Kurucu H, Bozbay S, et al. Co-existence of multiple sclerosis and anti-NMDA receptor encephalitis: a case report and review of literature. Mult Scler Relat Disord. 2020;42:102075. 
35. Uzawa A, Mori M, Takahashi Y, Ogawa Y, Uchiyama T, Kuwabara S. Anti-N-methyl $\mathrm{D}$-aspartate-type glutamate receptor antibody-positive limbic encephalitis in a patient with multiple sclerosis. Clin Neurol Neurosurg. 2012;114(4):402-404.

36. Auer M, Hegen H, Zeileis A, Deisenhammer F. Quantitation of intrathecal immunoglobulin synthesis-a new empirical formula. Eur J Neurol. 2016;23(4): 713-721.

37. Link H, Tibbling G. Principles of albumin and IgG analyses in neurological disorders. III. Evaluation of IgG synthesis within the central nervous system in multiple sclerosis. Scand J Clin Lab Invest. 1977;37(5):397-401.
38. Blennow K, Fredman P, Wallin A, et al. Formulas for the quantitation of intrathecal $\mathrm{IgG}$ production. Their validity in the presence of blood-brain barrier damage and their utility in multiple sclerosis. J Neurol Sci. 1994;121(1):90-96.

39. Balu R, McCracken L, Lancaster E, Graus F, Dalmau J, Titulaer MJ. A score that predicts 1-year functional status in patients with anti-NMDA receptor encephalitis. Neurology. 2019;92(3):e244-e252.

40. Yu Y, Wu Y, Cao X, et al. The clinical features and prognosis of anti-NMDAR encephalitis depends on blood brain barrier integrity. Mult Scler Relat Disord. 2021; 47(1): 102604 . 


\title{
Neurology \\ Neuroimmunology \& Neuroinflammation
}

\author{
CSF Findings in Acute NMDAR and LGI1 Antibody-Associated Autoimmune \\ Encephalitis \\ Marc Dürr, Gunnar Nissen, Kurt-Wolfram Sühs, et al. \\ Neurol Neuroimmunol Neuroinflamm 2021;8; \\ DOI 10.1212/NXI.0000000000001086
}

This information is current as of October 25, 2021

Updated Information \&

Services

References

Subspecialty Collections

Permissions \& Licensing

Reprints including high resolution figures, can be found at:

http://nn.neurology.org/content/8/6/e1086.full.html

This article cites 40 articles, 2 of which you can access for free at: http://nn.neurology.org/content/8/6/e1086.full.html\#\#ref-list-1

This article, along with others on similar topics, appears in the following collection(s):

Autoimmune diseases

http://nn.neurology.org//cgi/collection/autoimmune_diseases

Encephalitis

http://nn.neurology.org//cgi/collection/encephalitis

Information about reproducing this article in parts (figures,tables) or in its entirety can be found online at:

http://nn.neurology.org/misc/about.xhtml\#permissions

Information about ordering reprints can be found online:

http://nn.neurology.org/misc/addir.xhtml\#reprintsus

Neurol Neuroimmunol Neuroinflamm is an official journal of the American Academy of Neurology.

Published since April 2014, it is an open-access, online-only, continuous publication journal. Copyright

Copyright (C) 2021 The Author(s). Published by Wolters Kluwer Health, Inc. on behalf of the American

Academy of Neurology.. All rights reserved. Online ISSN: 2332-7812.

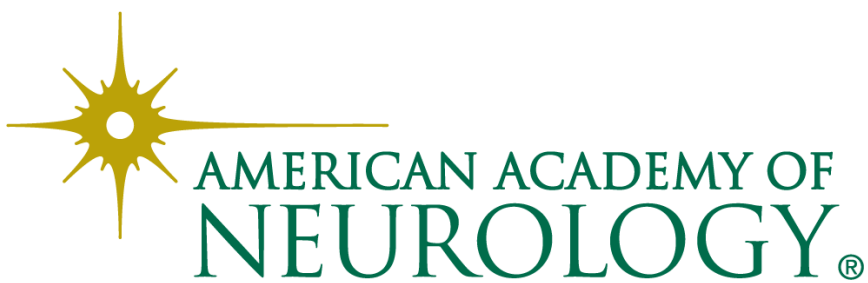

